\title{
Global and regional trends of aerosol optical depth over land and ocean using SeaWiFS measurements from 1997 to 2010
}

\author{
N. C. Hsu ${ }^{1}$, R. Gautam ${ }^{1,2}$, A. M. Sayer ${ }^{1,2}$, C. Bettenhausen ${ }^{1,3}$, C. Li ${ }^{1,4}$, M. J. Jeong ${ }^{5}$, S.-C. Tsay ${ }^{1}$, and B. N. Holben ${ }^{1}$ \\ ${ }^{1}$ NASA Goddard Space Flight Center, Greenbelt, MD, USA \\ ${ }^{2}$ Goddard Earth Sciences Technology And Research (GESTAR), Universities Space Research Association (USRA), \\ Columbia, MD, USA \\ ${ }^{3}$ Science Systems Applications Inc., Lanham, MD, USA \\ ${ }^{4}$ University of Maryland, College Park, MD, USA \\ ${ }^{5}$ Gangneung-Wonju National University, Gangneung City, Gangwon Province, Korea
}

Correspondence to: N. C. Hsu (christina.hsu@nasa.gov)

Received: 5 March 2012 - Published in Atmos. Chem. Phys. Discuss.: 29 March 2012

Revised: 15 August 2012 - Accepted: 22 August 2012 - Published: 10 September 2012

\begin{abstract}
Both sensor calibration and satellite retrieval algorithm play an important role in the ability to determine accurately long-term trends from satellite data. Owing to the unprecedented accuracy and long-term stability of its radiometric calibration, SeaWiFS measurements exhibit minimal uncertainty with respect to sensor calibration. In this study, we take advantage of this well-calibrated set of measurements by applying a newly-developed aerosol optical depth (AOD) retrieval algorithm over land and ocean to investigate the distribution of AOD, and to identify emerging patterns and trends in global and regional aerosol loading during its 13 -yr mission. Our correlation analysis between climatic indices (such as ENSO) and AOD suggests strong relationships for Saharan dust export as well as biomass-burning activity in the tropics, associated with large-scale feedbacks. The results also indicate that the averaged AOD trend over global ocean is weakly positive from 1998 to 2010 and comparable to that observed by MODIS but opposite in sign to that observed by AVHRR during overlapping years. On regional scales, distinct tendencies are found for different regions associated with natural and anthropogenic aerosol emission and transport. For example, large upward trends are found over the Arabian Peninsula that indicate a strengthening of the seasonal cycle of dust emission and transport processes over the whole region as well as over downwind oceanic regions. In contrast, a negative-neutral tendency is observed over the desert/arid Saharan region as well as in the associated dust outflow over the north Atlantic. Additionally, we found de-
\end{abstract}

creasing trends over the eastern US and Europe, and increasing trends over countries such as China and India that are experiencing rapid economic development. In general, these results are consistent with those derived from ground-based AERONET measurements.

\section{Introduction}

The impact of natural and anthropogenic sources of air pollution on Earth's weather and climate systems and their long-term tendencies have gained increasing attention from the scientific community in recent years (Mishchenko et al., 2007; Rosenfeld et al., 2008; Zhang and Reid, 2010). Indeed, tropospheric aerosols not only perturb the radiative energy balance by interacting with solar and terrestrial radiation ( $\mathrm{Ra}-$ manathan et al., 2001) but also by changing cloud properties and lifetimes (Rosenfeld et al., 2008). Furthermore, the Intergovernmental Panel on Climate Change (IPCC, 2007) report indicates that the aerosol cooling effect could have partially counteracted warming from greenhouse gas increases over the past few decades. However, there are large uncertainties in the estimation of climate forcing from aerosols due to their complex nature and short lifetime. In order to achieve a better understanding of the spatial and temporal variability of aerosol distributions on both regional and global scales, longterm satellite measurements of high fidelity are required. 
From this increased understanding we can then accurately evaluate aerosol effects in climate models.

Despite its importance, deriving the small signal that represents the long-term trend in aerosol distribution from the large seasonal cycles and natural year-to-year variability which result from large-scale meteorology is highly challenging. In order to use satellite measurements to determine aerosol trends with the required level of robustness, several key elements must be addressed. They include: (1) accuracy, precision, and stability of the sensor calibration, (2) potential for sampling bias due to insufficient temporal or spatial coverage, (3) potential for algorithm bias (i.e. differences in the cloud screening scheme, temporal changes in the aerosol or surface properties that deviate from assumptions used in the retrieval algorithm), (4) sufficient length of the data record, and (5) potential effects of any measurement time drift due to the diurnal cycle of atmospheric aerosol loading. Early satellite sensors, such as the Advanced Very High Resolution Radiometer (AVHRR), provide a longer data record for trend determination compared to later, more advanced satellite sensors such as the Sea-viewing Wide Field-of-view Sensor (SeaWiFS), Moderate Resolution Imaging Spectroradiometer (MODIS), Multiangle Imaging Spectroradiometer (MISR), and others. However, due to the limited number of spectral bands and the lack of onboard calibration for the early sensors, the uncertainty associated with trends calculated using measurements from them can be significant.

Among the suite of NASA's Earth Observing System (EOS)-era satellites, the SeaWiFS instrument was primarily designed to measure ocean color; since its launch in 1997, it has been the major source for providing a comprehensive global data set of such measurements. However, the unprecedented set of well-calibrated radiances measured in the wavelength range from the visible $(412 \mathrm{~nm})$ to the near infrared $(865 \mathrm{~nm})$ also make it well-suited to providing information about atmospheric aerosols (McClain et al., 1998). In this study, we will attempt to estimate trends in aerosol optical depth (AOD) at $550 \mathrm{~nm}$ over land and ocean using SeaWiFS measurements from 1997 to 2010 using a new SeaWiFS aerosol dataset that has been produced as part of NASA's MEaSUREs project (http://disc.sci.gsfc.nasa.gov/measures).

We begin in Sect. 2 by evaluating the performance of the sensor calibration and aerosol retrieval algorithm throughout the entire SeaWiFS mission. Section 3 describes our methodology for trend determination. This is followed, in Sect. 4, by a discussion of the resulting annual and seasonal trends from SeaWiFS and comparisons to ground-based measurements from the Aerosol Robotic Network (AERONET, Holben et al., 1998). A summary and conclusions based on our study are given in the closing section.

\section{Satellite data and their uncertainties for trend analysis}

Since $90 \%$ of the top-of-the-atmosphere (TOA) radiance received by a satellite sensor over ocean comes from contributions of the atmosphere such as molecular and aerosol scattering, less than $10 \%$ of the signal is attributable to the ocean itself (Gordon, 1997). Consequently, the level of accuracy, precision, and long-term stability needed in radiometric measurements from such a sensor are much higher for ocean color retrievals than those needed for corresponding land or atmospheric products. As a result of rigorous on-orbit calibration techniques developed using a combination of lunar and solar diffuser measurements and vicarious procedures, the NASA Ocean Biology Processing Group (OBPG) Calibration and Validation Team achieved an extraordinary level of absolute accuracy (1-2\%), precision $(0.1 \%)$ and, most importantly, long-term stability $(0.3 \%$ over the 13 -yr mission) for the TOA radiances from SeaWiFS (Eplee et al., 2011).

The SeaStar platform carrying SeaWiFS was launched with a nominal center-of-swath equatorial overpass time of around noon for the daytime (descending) node. This drifted slowly through the mission into a later orbit, although remained before 12:30 p.m. until 2005; the overpass time reached a maximum around 02:40 p.m. in July 2010, after which an orbit raising maneuver was performed to return the orbit slowly closer to noon. Smirnov et al. (2002) investigated the diurnal cycle of AOD at various AERONET sites. Over this range of local times, the change in mid-visible AOD was found to be of order of a few percent or less of the daily mean AOD for most aerosol types; the most rapid diurnal variability was generally in early morning or late afternoon. This suggests that the drift in SeaWiFS orbit time is unlikely to introduce significant artifacts into derived trends.

The SeaWiFS product used in this study is based upon the SeaWiFS v003 dataset, available from http://disc.gsfc.nasa. gov/dust. This dataset spans the time period September 1997 to December 2010 and is the result of an effort funded by NASA's MEaSUREs project to produce a long-term aerosol data record from SeaWiFS. This aerosol retrieval system utilizes a combination of the Deep Blue algorithm over land (Hsu et al., 2004, 2006) and the SeaWiFS Ocean Aerosol Retrieval (SOAR) algorithm over ocean (Sayer et al., 2012a). The Level 2 products are derived with a horizontal resolution of approximately $13.5 \mathrm{~km}$ at nadir and include spectral AOD at 412, 490, and $670 \mathrm{~nm}$, Ångström exponent, and single scattering albedo (for dust aerosols) over land, and spectral AOD at 510, 670, and $865 \mathrm{~nm}$, Ångström exponent, and fine mode fractional aerosol volume over ocean. The AOD at the reference wavelength of $550 \mathrm{~nm}$ are also reported for both land and ocean (cf. Hsu et al., 2004 and Sayer et al., 2012a for details). Level 3 (gridded) products are available for daily and monthly averages at both $0.5^{\circ} \times 0.5^{\circ}$ and $1^{\circ} \times 1^{\circ}$ resolutions. Figure 1 shows an example of the 
resulting seasonally-averaged AOD at $550 \mathrm{~nm}$ throughout the 13-yr mission using this newly-developed product. In this study, we used the Level $31^{\circ} \times 1^{\circ}$ spatial resolution monthly mean SeaWiFS AOD data at $550 \mathrm{~nm}$ to calculate aerosol trends which can be compared efficiently with other satellite products.

A detailed validation of the global SeaWiFS AOD using the collocated v003 Level 2 products against cloud-screened and quality-assured Level 2 AERONET measurements (Holben et al., 1998; Smirnov et al., 2000) and other satellite products is presented for land in Sayer et al. (2012a) and for ocean in Sayer et al. (2012b). Briefly, on a global basis, over one standard deviation $(68 \%)$ of AOD matchups were found to agree within an absolute expected error of $0.03+15 \%$ over ocean and $0.05+20 \%$ over land at $550 \mathrm{~nm}$. Since a change in the quality of the retrieval with time, due to either calibration drift or other factors described in Sect. 1, could mask or amplify any true change in AOD, it was also imperative to make an assessment of the temporal stability for this dataset. We therefore calculated the differences in $550 \mathrm{~nm}$ AOD between SeaWiFS and AERONET data as a function of year over ocean and land separately; the results are depicted in Fig. 2 (methodology and general validation results are presented by Sayer et al., 2012a, b). Only the best quality SeaWiFS data, with a quality assurance (QA) of 3 over land and a QA of 2 and 3 over ocean, are included in our analyses (as recommended in the aforementioned references). Also, in order to ensure the consistency of AERONET measurement locations throughout the SeaWiFS lifetime, only AERONET sites with records lasting for most or all of the SeaWiFS time series are considered, as otherwise an apparent change in comparison statistics could simply be the result of changes in regional sampling.

For retrievals over land, the stations used in our analysis are Alta Floresta $\left(9^{\circ} \mathrm{S}, 56^{\circ} \mathrm{W}\right)$, Avignon $\left(43^{\circ} \mathrm{N}, 4^{\circ} \mathrm{E}\right)$, Banizoumbou $\left(13^{\circ} \mathrm{N}, 2^{\circ} \mathrm{E}\right)$, Beijing $\left(39^{\circ} \mathrm{N}, 116^{\circ} \mathrm{E}\right)$, Bondville $\left(40^{\circ} \mathrm{N}, 88^{\circ} \mathrm{W}\right)$, Bratts Lake $\left(50^{\circ} \mathrm{N}, 104^{\circ} \mathrm{W}\right)$, the CART site $\left(36^{\circ} \mathrm{N}, 97^{\circ} \mathrm{W}\right)$, Dakar $\left(14^{\circ} \mathrm{N}, 16^{\circ} \mathrm{W}\right)$, Dalanzadgad $\left(43^{\circ} \mathrm{N}, 104^{\circ} \mathrm{E}\right), \mathrm{GSFC}\left(38^{\circ} \mathrm{N}, 76^{\circ} \mathrm{W}\right), \mathrm{HJ}$ Andrews $\left(44^{\circ} \mathrm{N}\right.$, $\left.122^{\circ} \mathrm{W}\right)$, Ilorin $\left(8^{\circ} \mathrm{N}, 4^{\circ} \mathrm{E}\right)$, IMS METU-Erdemli $\left(36^{\circ} \mathrm{N}\right.$, $\left.34^{\circ} \mathrm{E}\right)$, Ispra $\left(45^{\circ} \mathrm{N}, 8^{\circ} \mathrm{E}\right)$, Kanpur $\left(26^{\circ} \mathrm{N}, 80^{\circ} \mathrm{E}\right)$, MD Science Center $\left(39^{\circ} \mathrm{N}, 76^{\circ} \mathrm{W}\right)$, Mongu $\left(15^{\circ} \mathrm{S}, 23^{\circ} \mathrm{E}\right)$, Sede Boker $\left(30^{\circ} \mathrm{N}, 34^{\circ} \mathrm{E}\right)$, Sevilleta $\left(34^{\circ} \mathrm{N}, 106^{\circ} \mathrm{W}\right)$, Skukuza $\left(24^{\circ} \mathrm{S}, 31^{\circ} \mathrm{E}\right)$, Solar Village $\left(25^{\circ} \mathrm{N}, 46^{\circ} \mathrm{E}\right)$, and Wallops $\left(37^{\circ} \mathrm{N}, 75^{\circ} \mathrm{W}\right)$. Figure 2 shows that the median and mean AOD difference between SeaWiFS and AERONET for these sites is generally small and negative. Therefore, for a typical case, SeaWiFS is likely to exhibit a slightly low bias. The lines are reasonably stable over time, suggesting that the quality of the dataset does not change throughout the SeaWiFS mission. The intercept of the best-fit line of the mean error against time is $-0.016( \pm 0.007)$, with a gradient of $0.0003( \pm 0.0009)$ per year (both in units of absolute AOD). Therefore, the temporal bias is not statistically different from zero at the $95 \%$ level (quoted fit uncertainties are the one- sigma, i.e. $68 \%$, confidence limits). Variation from year-toyear appears smooth, with no abrupt changes.

Over ocean, fewer sites are available, particularly for the early part of the time series, so only the years 19992010 are considered, from the AERONET sites at Arica $\left(18^{\circ} \mathrm{S}, 70^{\circ} \mathrm{W}\right)$, Capo Verde $\left(16^{\circ} \mathrm{N}, 22^{\circ} \mathrm{W}\right)$, Dakar $\left(14^{\circ} \mathrm{N}\right.$, $\left.16^{\circ} \mathrm{W}\right)$, Helgoland $\left(54^{\circ} \mathrm{N}, 7^{\circ} \mathrm{E}\right)$, IMS METU-Erdemli $\left(36^{\circ} \mathrm{N}, 34^{\circ} \mathrm{E}\right)$, La Parguera $\left(17^{\circ} \mathrm{N}, 67^{\circ} \mathrm{W}\right)$, Nauru $\left(0^{\circ} \mathrm{S}\right.$, $\left.166^{\circ} \mathrm{E}\right)$, Shirahama $\left(33^{\circ} \mathrm{N}, 135^{\circ} \mathrm{E}\right)$, and Venise $\left(45^{\circ} \mathrm{N}\right.$, $\left.12^{\circ} \mathrm{E}\right)$. The intercept of $-0.008( \pm 0.005)$ and gradient of $-0.0014( \pm 0.0008)$ per year of the best-fit line are not significantly different from zero at the $95 \%$ confidence level (the gradient is significant at the $90 \%$ level, but is small in magnitude).

These results give confidence that the SeaWiFS aerosol dataset is suitable for the analysis of changes in AOD over this period. This does, of course, rely on the assumption that the evaluation at these sites is a good representation of the whole globe, although in the absence of long-term aerosol measurements at every location, this cannot be assessed directly.

\section{Methodology}

In order to show changes in spatial and temporal distribution of aerosol loading, linear trends were calculated based on the $1^{\circ} \times 1^{\circ}$ spatial resolution monthly mean SeaWiFS AOD data, from September 1997 to December 2010. These monthly datasets are calculated as the simple mean of the daily mean AOD for each month; the daily mean is computed from all those retrievals of sufficiently high QA (2 or 3 over ocean, and 3 over land). An additional criterion used in the creation of the monthly mean AOD dataset is that each $1^{\circ} \times 1^{\circ}$ region must consist of at least $20 \%$ of the available daily mean data. If this condition is not met, monthly mean AOD for that $1^{\circ} \times 1^{\circ}$ region is not calculated and therefore not included in the trend analysis. In order to remove the large influence of the annual cycle, the data were first deseasonalized by obtaining the time series of AOD anomaly for each grid cell. The anomaly is defined as difference between monthly variation and climatology (i.e. the month-wise average over all the years). A least-squares fit was applied to the AOD anomaly time series to get the slope coefficient of the linear regression that represents annual trend ( $\mathrm{AOD} \mathrm{yr}^{-1}$ ).

The statistical significance of the calculated trends has been assessed using the method of Weatherhead et al. (1998), which has been applied in many studies, including those related to AOD trends (e.g. Zhang and Reid, 2010; Yoon et al., 2011; de Meij et al., 2012). The relevant details are summarized here, although Weatherhead et al. (1998) present a thorough discussion and derivation. This treats the trend as a simple linear model,

$Y_{t}=\mu+\omega X_{t}+N_{t} t=1, \ldots, T$ 

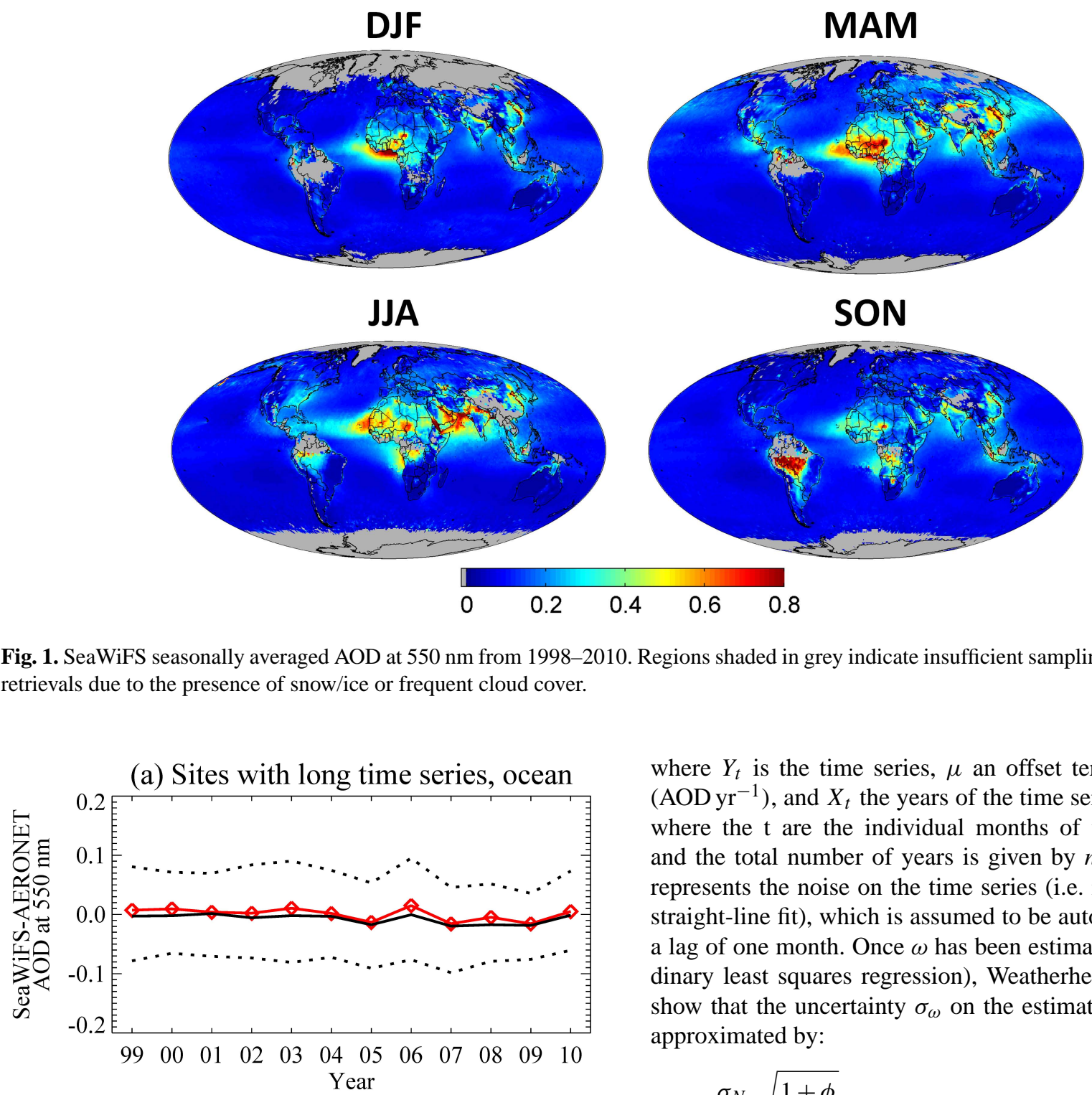

Fig. 1. SeaWiFS seasonally averaged AOD at $550 \mathrm{~nm}$ from 1998-2010. Regions shaded in grey indicate insufficient sampling sizes of aerosol retrievals due to the presence of snow/ice or frequent cloud cover.

(b) Sites with long time series, land

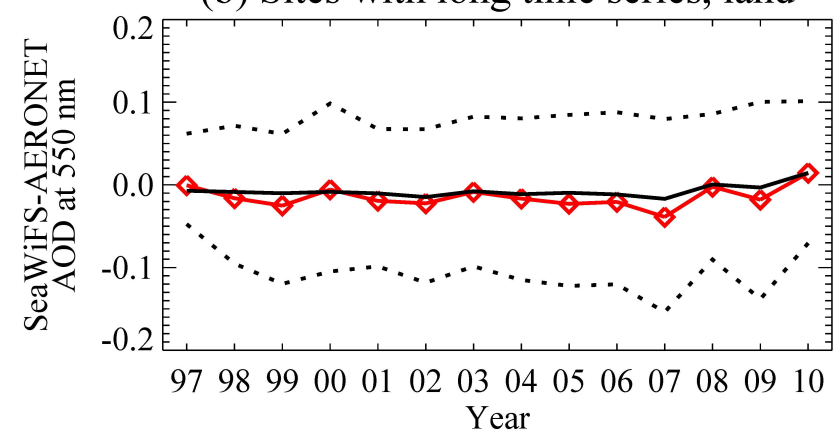

Fig. 2. Yearly variations in the differences between SeaWiFS and AERONET AOD over (a) ocean and (b) land. Red is the mean difference in each year, while solid black is the median for each year. Dotted black are the range of the central $68 \%$ of the data. where $Y_{t}$ is the time series, $\mu$ an offset term, $\omega$ the trend $\left(\mathrm{AOD} \mathrm{yr}{ }^{-1}\right)$, and $X_{t}$ the years of the time series $\left(X_{t}=t / 12\right.$, where the $t$ are the individual months of the time series, and the total number of years is given by $n$ ). The term $N_{t}$ represents the noise on the time series (i.e. residuals on the straight-line fit), which is assumed to be autoregressive with a lag of one month. Once $\omega$ has been estimated (through ordinary least squares regression), Weatherhead et al. (1998) show that the uncertainty $\sigma_{\omega}$ on the estimated trend can be approximated by:

$\sigma_{\omega} \approx \frac{\sigma_{N}}{n^{3 / 2}} \sqrt{\frac{1+\phi}{1-\phi}}$

In the above $\sigma_{N}$ is the standard deviation of the residuals $N_{t}$ on the fit, and $\phi$ the autocorrelation coefficient. From the above equation it follows that when the time series shows positive autocorrelation $\sigma_{\omega}$ increases, i.e. confident detection of the trend becomes more difficult. The significance of the trend is assessed using the ratio $\left|\omega / \sigma_{\omega}\right|$ (i.e. the absolute trend relative to its uncertainty); if this ratio is 2 or more, the trend is significant at the $95 \%$ confidence level. Unless stated otherwise, the term "significance" in this work refers to such trends. Similarly, significance at the $90 \%$ level is found for $\left|\omega / \sigma_{\omega}\right|>1.65$ (the z-score of the $10 \%$ point of the Normal distribution).

In most areas of the world, the magnitude of the autocorrelation coefficient was found to be small (less than 0.2), such that the significance level calculated using this method is similar to that using other techniques such as the Student's 
t-test. Additionally, as least-squares regression can be sensitive to outliers, autocorrelation, and heteroscedasticity of errors in the input data, linear AOD trends were also estimated using the non-parametric Theil-Sen (aka "median gradients") method, which is an estimator robust to these difficulties (Theil, 1950; Sen, 1968). Global trends calculated using the Theil-Sen method were within approximately $10 \%$ of the least-squares regression values for all the sensors considered, suggesting the least-squares model is appropriate for this situation.

\section{Results and discussions}

\subsection{Correlations between SeaWiFS AOD anomaly with ENSO and NAO}

In order to estimate global and regional trends in AOD, we need to first examine the inter-annual variability of the aerosol distribution and its relationship with large-scale climatic variations such as the El Niño/La Niña-Southern Oscillation (ENSO) and the North Atlantic Oscillation (NAO). These large-scale meteorological processes could perturb the aerosol distributions through changes in aerosol emissions by altering the precipitation and/or soil moisture, or through aerosol transport via atmospheric circulation feedbacks. The correlation coefficients $(R)$ are thus calculated between deseasonalized monthly SeaWiFS AOD anomalies and the Multivariate ENSO Index (MEI; Wolter and Timlin, 1993, 1998) from 1997 to 2010.

As shown in Fig. 3a, the most prominent regions of high correlation with ENSO signatures are in the tropics near Indonesia and Central America. In Indonesia/Borneo, fires are primarily used to clear vegetation waste associated with deforestation for agricultural expansion and usually peak in the fall and spring season, when the air is relatively dry and precipitation is low. These smoke plumes, which can often stretch over hundreds of kilometers, are readily observed by satellites. The times series of SeaWiFS monthly AOD anomaly along with ENSO index is shown in Fig. 4 and indicates that the intensity of resulting smoke is predominantly linked to El-Nino-induced droughts over this region; strong peaks are seen in the years 1997-1998, 2002, and 2006.

Since the amount of precipitation affects the interannual variability of biomass burning activities and dust emission through changes in soil moisture, these effects could be accumulative. We also calculate the correlation coefficients between SeaWiFS AOD anomaly and the ENSO index with various time lags. Figure $3 \mathrm{~b}$ and $\mathrm{c}$ show AOD anomaly correlations with ENSO index leading by six months and one year, respectively. We note that the intensity of biomass burning smoke in Central America is sensitive not only to the ENSOinduced rainfall changes during the peak burning season, but also to those accumulated throughout several months prior to the start of burning (i.e. on a 6-month time lag as shown

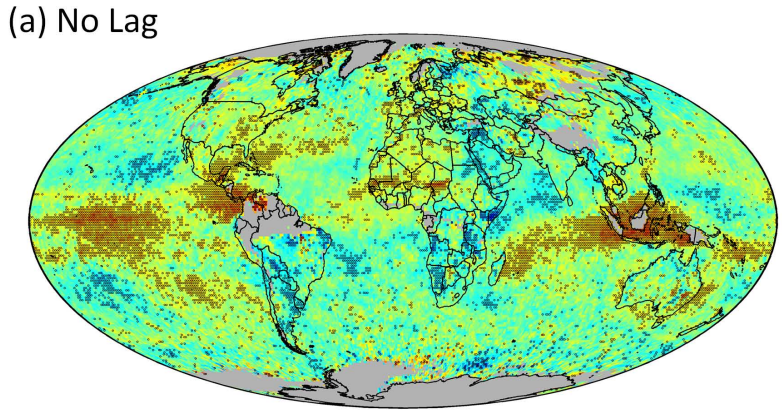

(b) 6-Month Lag

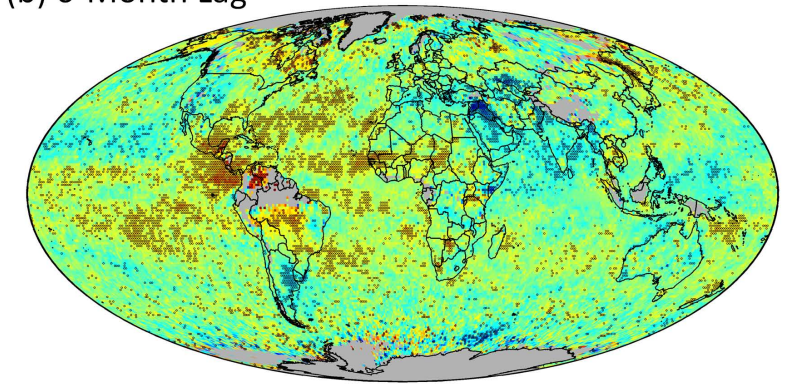

(c) 1-Year Lag

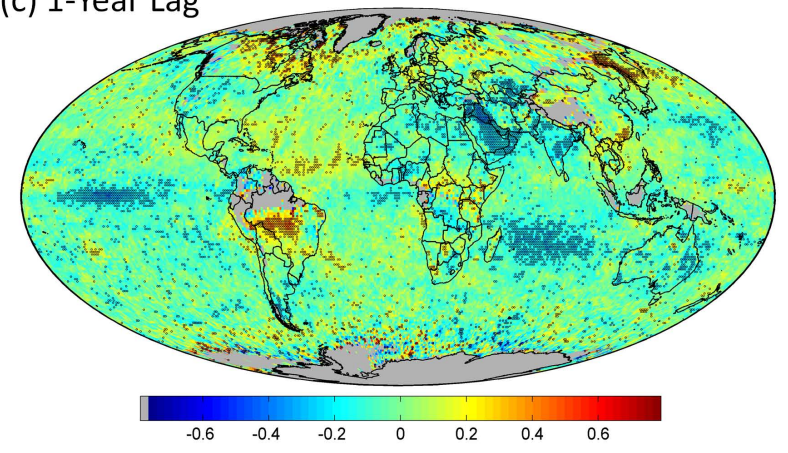

Fig. 3. Correlation coefficients of SeaWiFS deseasonalized monthly AOD anomaly with the multivariate ENSO index (MEI) (a) from the same month (no lag), (b) leading by 6 months, and (c) leading by 1 yr. Dots indicate significance at $95 \%$ confidence level. Regions shaded in grey indicate insufficient aerosol sample sizes.

in Fig. 3b). The lag time for South America appears to be even longer (6 months to a year) compared to that for Central America. Such time lags between ENSO and fire season severity in South America have also been reported by Chen et al. (2011), with significant lagged correlations emerging on a 3-7 month time scale. However, there seems to be little time lag observed over Indonesia between AOD anomaly and ENSO-induced drought. This is probably indicative of the differences in agriculture/land clearing practices between South America, Central America, and Indonesia.

The results shown in Fig. 5 indicate that summertime Saharan dust loadings highly correlate $(R>0.5$ at $95 \%$ confidence) with the ENSO index from 6 months earlier over dust source regions in northern Sahel, as well as over the Atlantic along the dust transport pathway reaching as far as Barbados, 


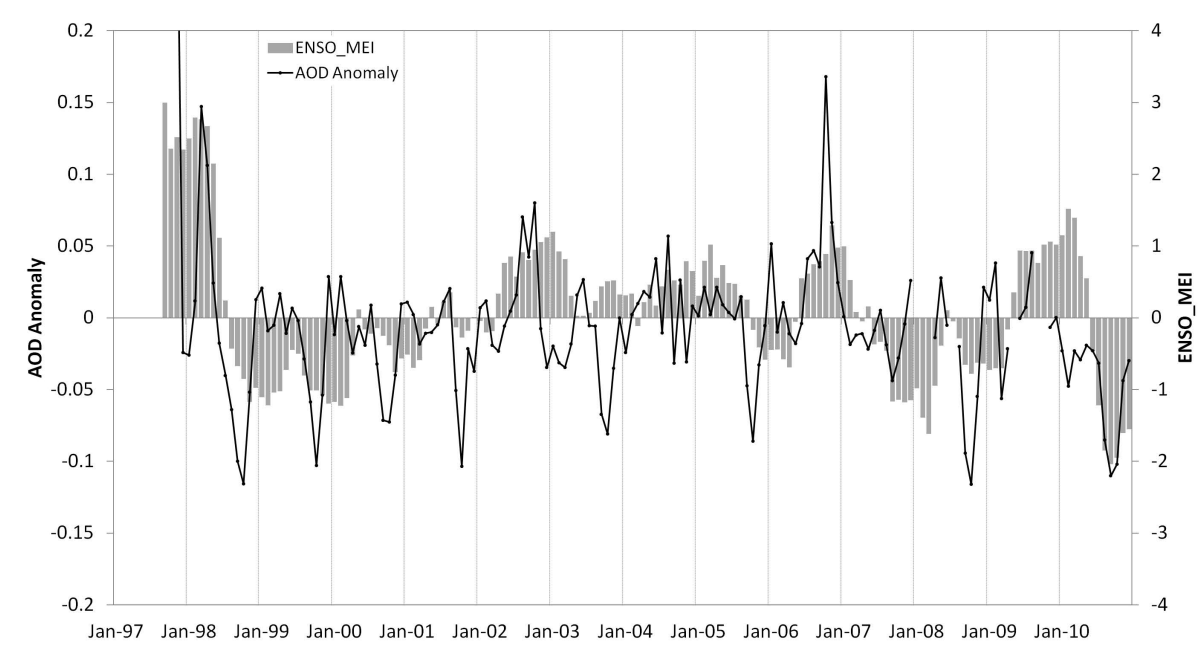

Fig. 4. Time series of AOD anomaly and ENSO Index over Indonesia region $\left(8^{\circ} \mathrm{S}-8^{\circ} \mathrm{N}, 90-130^{\circ} \mathrm{E}\right)$.

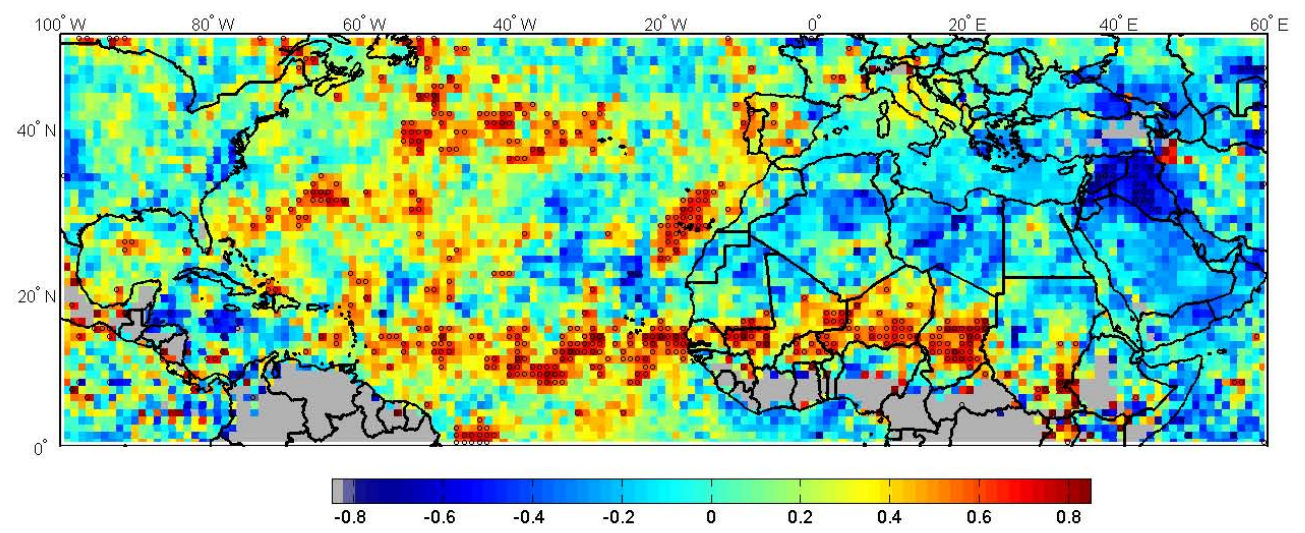

Fig. 5. Lagged correlation of summertime average (JJA) mean AOD anomaly with winter (DJ) mean ENSO Index leading by 6 months over the North Atlantic and surrounding regions $\left(0-50^{\circ} \mathrm{N}, 100^{\circ} \mathrm{W}-60^{\circ} \mathrm{E}\right)$. Dots indicate significance at $95 \%$ confidence level. Regions shaded in grey indicate insufficient aerosol sample sizes.

West Indies. This is consistent with the findings of Prospero and Lamb (2003) and Chiapello et al. (2005), who reported a close link between dust concentrations observed in Barbados followed by the occurrence of major ENSO events and the associated drought in Sahel. In contrast to the Sahara, which receives little rainfall each year, dust emissions over the Sahel are apparently more influenced by the year-to-year variability of the precipitation, as expected. Besides the transport route from the Sahel to Barbados, the high ENSO/AOD correlation results shown in Fig. 5 also indicate the possibility of a widespread association between ENSO and dust transport in the western and northern parts of the North Atlantic along the edge of the Saharan dust outflow regions. This anomalous pattern also coincides with the main development region (MDR), primarily between $10-20^{\circ} \mathrm{N}$, of tropical cyclone activity in the Atlantic. This is likely to be linked to the effects of ENSO induced changes of the atmospheric dynamics and circulation on the summer time Saharan dust transport into the Atlantic.

The effects of the NAO on the Saharan dust distribution are also investigated as shown in Fig. 6. The NAO is one of the dominant factors of northern winter (December-JanuaryFebruary) climate variability in the North Atlantic region, spanning central North America and Europe. The NAO winter index used in this study is based upon the difference of normalized sea level pressure between Lisbon, Portugal and Stykkisholmur, Iceland (Hurrell, 1995). Based upon the results in Fig. 6, a sizeable and statistically significant (at $95 \%$ confidence) correlation $(R>0.5)$ is apparent between the SeaWiFS AOD anomaly and NAO index over extensive areas encompassing the western part of the North African continent into the North Atlantic. In addition, we also observe a secondary branch of positive correlation that is statistically significant along the pollution outflow of the eastern US across the most northern edge of the Atlantic. We found 
no statistically significant correlation over this region for seasons other than winter. This is consistent with the findings of Ginoux et al. (2004) and Chiapello et al. (2005) based upon the 17-yr record of TOMS data (1979-2000, except for 1982 and 1993-1996).

These results suggest that, while the NAO has a large influence on the wintertime dust distribution over the Atlantic, significant variability of the AOD anomaly in this region is influenced by ENSO during the summer months. We also note that large scale meteorological events such as ENSO and NAO appear to have significant impacts on the interannual variability of aerosol distribution in the dust-laden regions such as the Sahel, western part of North Africa, and the surrounding waters, as well as in the biomass burning smokedominated regions such as South America and the equatorial zone in Southeast Asia. Therefore, trend determination in such regions is more susceptible to the influence of these large-scale climatic driving forces, which result in larger interannual variability in AOD and consequently less likely to meet the level of statistical significance as described in the next section.

\subsection{Global trend}

Figure 7 shows comparisons of the time series of absolute AOD and AOD anomaly averaged over global ocean from SeaWiFS with those from MODIS Terra (data record beginning in 2000) and Aqua (beginning 2002) during their overlapping years. Although there is an offset between MODIS Terra and Aqua in terms of absolute values of AOD, the short-term tendency during the overlapping period is similar between the two (Zhang and Reid, 2010). This comparison shows that the interannual variability of the SeaWiFS AOD anomaly follows both MODIS Terra and Aqua until mid- 2009. From 2009 onwards, the SeaWiFS AOD anomaly is higher than that from MODIS, resulting in a more positive trend (i.e. $0.00098 \pm 0.00023 \mathrm{yr}^{-1}$ with $\left|\omega / \sigma_{\omega}\right|$ of 4.3) over global ocean compared to the MODIS values (i.e. $0.00061 \pm 0.00029 \mathrm{yr}^{-1}$ with $\left|\omega / \sigma_{\omega}\right|$ of 2.1 ) over an overlapping period of eleven years (2000-2010). According to Fig. 2, the comparisons of SeaWiFS retrieved AOD at $550 \mathrm{~nm}$ with the AERONET values do not indicate any significant drift from the zero line after the mid 2009, and thus suggests that the satellite-derived aerosol trend is likely not to be dominated by sensor calibration drift.

It is worth pointing out that long-term global ocean AOD measurements based on AVHRR data have been shown to have a downward tendency for the period 1982-2005 (Mischenko et al., 2007; Zhao et al., 2008). Although revised calibration procedures applied to AVHRR radiances have broadly resulted in comparable AOD when compared to MODIS (Zhao et al., 2008; Li et al., 2009), the short-term trends of AOD in the period of overlap between MODIS and AVHRR are opposite in sign (positive for MODIS and negative for AVHRR) for the period 2000-2005 (Li et al., 2009;
Zhang and Reid, 2010). This downward trend in AVHRR data continues until 2009, based on our analysis of the AVHRR Pathfinder Atmospheres - Extended (PATMOS-x) AOD data (not shown), which is in contrast to the trends observed from SeaWiFS and MODIS from this study.

The difference in sign associated with trends in the past decade could partly be due to the overall calibration accuracy/orbital drift in the AVHRR data record. Thomas et al. (2010) compared changes in AOD between Along-Track Scanning Radiometer 2 (ATSR-2) and AVHRR data for 1995-2001. They found that the global downward trend in the AVHRR AOD was largely driven by the southern oceans, for which the latitudinal range of sampling during daylight hours changed significantly during the study period, due to drifts in the AVHRR platform's orbit. Even for those regions where daylight availability is not an issue, diurnal variability in cloud cover can lead to changes in the availability of clearsky pixels for AOD retrieval as the satellites drift, resulting in further sampling bias (e.g. Devasthale et al., 2012). The drifts in orbit time for the AVHRR sensors were generally larger than for SeaWiFS, and when compositing multiple AVHRR records together to create a longer time series, there are time discontinuities when one satellite is replaced by the next. Additionally, other factors contributing to this noted difference may be related to data sampling issues arising from different cloud-screening schemes employed by AVHRR and SeaWiFS/MODIS.

Also shown in Fig. 7 is the time series of over-ocean AOD and anomaly from the data assimilation (DA) grade MODISTerra dataset, which is a product based on bias correction and additional quality screening of the MODIS Collection 5 aerosol product (Zhang and Reid, 2006; Shi et al., 2011). Only the period 2000-2009 is available. These data track the SeaWiFS record very closely. This is consistent with Sayer et al. (2012), who found for collocated daily Terra/DA-MODIS and SeaWiFS data over ocean a correlation of 0.87 and bias of -0.006 between the two (SeaWiFS lower). In contrast, the Collection 5 MODIS Terra had a slightly lower correlation with SeaWiFS (0.80), and SeaWiFS a more negative bias ( -0.027$)$. Only Terra data are shown; the offset between the two MODIS sensors becomes smaller in the DA-MODIS product (Shi et al., 2011; Sayer et al., 2012).

Zhang and Reid (2010) found, using a similar methodology to this study, an annual trend of $0.001 \mathrm{yr}^{-1}$ based upon ten-year (2000-2009) global-average over-ocean Terra/DAMODIS AOD (and a similar figure noted for Aqua). This is in good agreement with the results of this study from both the DA-MODIS and SeaWiFS records. However, after performing a correction to both the Terra and Aqua data to account for a drift in the quality of the validation statistics against AERONET since 2005 (Levy et al., 2010; Zhang and Reid, 2010), the magnitude of this trend decreased by a factor of three, and it became statistically insignificant. Their best estimate is therefore that there has been no significant change in global-average over-ocean AOD during this period. 


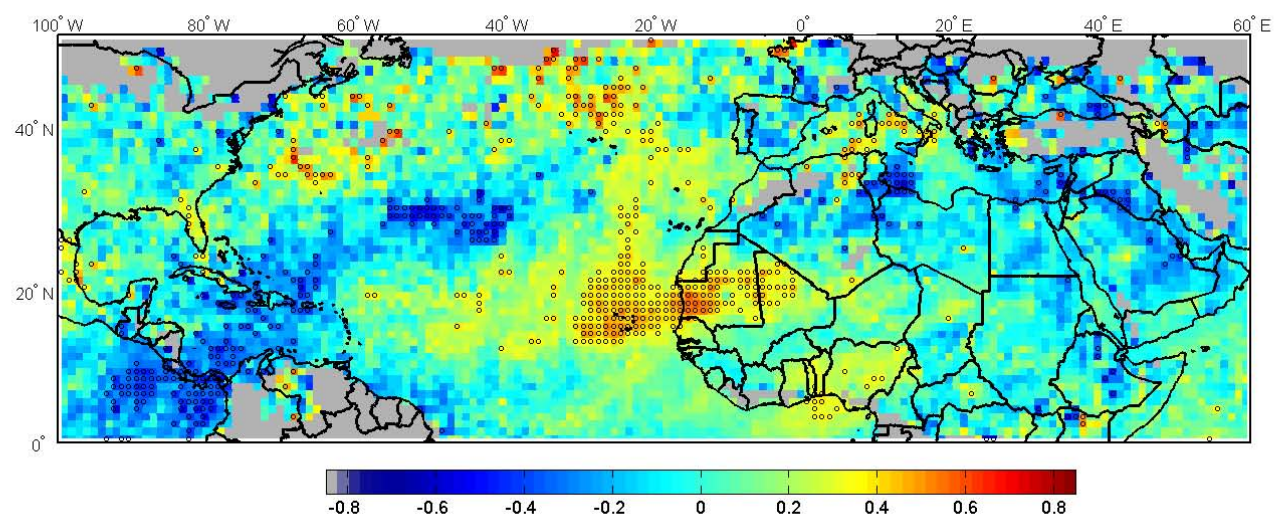

Fig. 6. Correlation of AOD anomaly and NAO Index during winter (DJF) months over the North Atlantic and surrounding regions $\left(0-50^{\circ} \mathrm{N}\right.$, $100^{\circ} \mathrm{W}-60^{\circ} \mathrm{E}$ ). Dots indicate significance at $95 \%$ confidence level. Regions shaded in grey indicate insufficient aerosol sample sizes.

Table 1. Global and regional annual trends derived based upon 13-yr SeaWiFS AOD products (January 1998-December 2010). The corresponding uncertainties are the $68 \%$ confidence limit. The derived trends in the regions with $\left|\omega / \sigma_{\omega}\right|>2$ are considered to be statistically significant at $95 \%$ confidence level.

\begin{tabular}{lllrrr}
\hline & $\begin{array}{l}\text { Latitude } \\
\left(^{\circ}\right)\end{array}$ & $\begin{array}{l}\text { Longitude } \\
\left(^{\circ}\right)\end{array}$ & $\begin{array}{r}\text { Slope AOD/ } \\
\text { per year }\end{array}$ & Uncertainty & $\left|\omega / \sigma_{\omega}\right|$ \\
\hline Global land/ocean & & & 0.00078 & 0.00019 & 4.00 \\
Global land & & & 0.00058 & 0.00041 & 1.39 \\
Global ocean & & & 0.00080 & 0.00019 & 4.21 \\
Africa (Sahel) & $10-15^{\circ} \mathrm{N}$ & $5^{\circ} \mathrm{W}-15^{\circ} \mathrm{E}$ & 0.0049 & 0.0031 & 1.55 \\
Arabian Peninsula & $10-35^{\circ} \mathrm{N}$ & $35-60^{\circ} \mathrm{E}$ & 0.0092 & 0.0013 & 7.18 \\
Central America & $5-20^{\circ} \mathrm{N}$ & $80-120^{\circ} \mathrm{W}$ & -0.0020 & 0.0014 & 1.45 \\
Eastern China & $35-40^{\circ} \mathrm{N}$ & $110-120^{\circ} \mathrm{E}$ & 0.0032 & 0.0018 & 1.79 \\
Southern China & $20-30^{\circ} \mathrm{N}$ & $108-120^{\circ} \mathrm{E}$ & 0.0049 & 0.0018 & 2.69 \\
Europe & $43-55^{\circ} \mathrm{N}$ & $0-30^{\circ} \mathrm{E}$ & -0.0027 & 0.0007 & 3.66 \\
Northern India & $20-30^{\circ} \mathrm{N}$ & $75-85^{\circ} \mathrm{E}$ & 0.0063 & 0.0020 & 3.20 \\
Eastern USA & $30-45^{\circ} \mathrm{N}$ & $70-90^{\circ} \mathrm{W}$ & -0.0028 & 0.0005 & 4.73 \\
North Atlantic (east) & $10-30^{\circ} \mathrm{N}$ & $18-30^{\circ} \mathrm{W}$ & -0.0040 & 0.0014 & 2.81 \\
South America & $10-20^{\circ} \mathrm{S}$ & $40-65^{\circ} \mathrm{W}$ & -0.0009 & 0.002 & 0.47 \\
Southeast Asia & $15^{\circ} \mathrm{S}-10^{\circ} \mathrm{N}$ & $80-120^{\circ} \mathrm{E}$ & 0.00011 & 0.001 & 0.11 \\
\hline
\end{tabular}

The resulting annual trends of SeaWiFS AOD anomaly over both land and ocean are derived for each $1^{\circ} \times 1^{\circ}$ grid cell over $13 \mathrm{yr}$ (January 1998 to December 2010) and are shown in Fig. 8. Overlaid symbols indicate regions with trends significant at the $95 \%$ confidence level (i.e. $\left|\omega / \sigma_{\omega}\right|>2$ ), following the Weatherhead et al. (1998) methodology as discussed in Sect. 3. The corresponding global mean as well as regionally averaged values of SeaWiFS derived annual trends and their uncertainties are included in Table 1.

For comparison, we also calculate trends based upon AERONET measurements over selected sites using the same methodology, where sufficient and more-or-less continuous data records were acquired over a similar time period to SeaWiFS. These AERONET values and the corresponding SeaWiFS trends are listed in Table 2. Also, to help visualize the SeaWiFS and AERONET trend comparisons in the context of the surrounding regions and over the whole globe, we superimpose the locations of AERONET sites on top of the SeaWiFS annual trend map in Fig. 8. The black and pink boxes and symbol $(\mathrm{x})$ represent positive, negative and negligible trends from AERONET data, respectively.

In general, the SeaWiFS derived annual trends from 1998 to 2010 are small over most of the world. As tabulated in Table 1, the trend values are found to be $0.00078 \pm 0.00019 \mathrm{yr}^{-1}$ with $\left|\omega / \sigma_{\omega}\right|$ of 4.00 for global average of land and ocean, and $0.00080 \pm 0.00019 \mathrm{yr}^{-1}$ with $\left|\omega / \sigma_{\omega}\right|$ of 4.21 for global ocean. Both trends meet the statistical significance of $95 \%$ confidence level. There is no statistically-significant trend detected in the global averaged AOD anomaly over land $\left(0.00058 \pm 0.00041 \mathrm{yr}^{-1}\right.$ with $\left|\omega / \sigma_{\omega}\right|$ of 1.39). However, on the regional scales, the trends could be considerable. For example, over the mineral dust dominant regions, strong positive trends are seen over 
Table 2. Comparisons of SeaWiFS-derived annual trends with those from AERONET measurements. Quoted uncertainties are the $68 \%$ confidence limit. ** indicates trends significant at $95 \%, *$ indicates trends significant at $90 \%$.

\begin{tabular}{|c|c|c|c|c|c|c|}
\hline & \multirow[t]{2}{*}{ Location } & \multirow[t]{2}{*}{ Time Period } & \multicolumn{2}{|c|}{ AERONET } & \multicolumn{2}{|c|}{ SeaWiFS } \\
\hline & & & Trend $\left(\mathrm{AOD} \mathrm{yr}^{-1}\right)$ & Uncertainty & Trend (AOD $\left.\mathrm{yr}^{-1}\right)$ & Uncertainty \\
\hline \multicolumn{7}{|l|}{ Ocean } \\
\hline Capo Verde & $16^{\circ} \mathrm{N}, 22^{\circ} \mathrm{W}$ & 01/1998-12/2010 & $-0.0040 *$ & 0.0024 & $-0.0070^{*}$ & 0.0039 \\
\hline COVE & $36^{\circ} \mathrm{N}, 75^{\circ} \mathrm{W}$ & 10/1999-01/2008 & -0.0010 & 0.0015 & -0.0023 & 0.0018 \\
\hline Ascension Island & $7^{\circ} \mathrm{S}, 14^{\circ} \mathrm{W}$ & 11/1998-11/2009 & 0.0012 & 0.0021 & 0.000063 & 0.0011 \\
\hline Nauru & $0^{\circ} \mathrm{S}, 166^{\circ} \mathrm{E}$ & 06/1999-11/2010 & 0.0013 & 0.00095 & 0.00066 & 0.00077 \\
\hline Tahiti & $17^{\circ} \mathrm{S}, 149^{\circ} \mathrm{W}$ & 07/1999-10/2009 & 0.00022 & 0.00086 & $0.0012 * *$ & 0.00063 \\
\hline Shirahama & $33^{\circ} \mathrm{N}, 135^{\circ} \mathrm{E}$ & $10 / 2000-01 / 2010$ & 0.000063 & 0.0022 & 0.0025 & 0.0017 \\
\hline La Parguera & $17^{\circ} \mathrm{N}, 67^{\circ} \mathrm{W}$ & 07/2000-07/2010 & 0.0014 & 0.0015 & -0.00071 & 0.0020 \\
\hline Venise & $45^{\circ} \mathrm{N}, 12^{\circ} \mathrm{E}$ & $06 / 1999-12 / 2010$ & $-0.0062 * *$ & 0.0015 & $-0.0053^{* *}$ & 0.0013 \\
\hline \multicolumn{7}{|l|}{ Land } \\
\hline IFT-Leipzig & $51^{\circ} \mathrm{N}, 12^{\circ} \mathrm{E}$ & 05/2001-05/2010 & $-0.009 * *$ & 0.0042 & $-0.0128 * *$ & 0.0057 \\
\hline GSFC & $38^{\circ} \mathrm{N}, 76^{\circ} \mathrm{W}$ & 09/1997-12/2010 & $-0.0039 * *$ & 0.0012 & -0.0008 & 0.0017 \\
\hline Alta_Floresta & $9^{\circ} \mathrm{S}, 56^{\circ} \mathrm{W}$ & 01/1999-12/2010 & 0.0005 & 0.0095 & -0.0093 & 0.032 \\
\hline Banizoumbou & $13^{\circ} \mathrm{N}, 2^{\circ} \mathrm{E}$ & 06/1999-06/2010 & 0.0087 & 0.0057 & $0.0136 * *$ & 0.0066 \\
\hline Solar Village & $25^{\circ} \mathrm{N}, 46^{\circ} \mathrm{E}$ & 02/1999-04/2010 & $0.018 * *$ & 0.0038 & $0.0097 * *$ & 0.0037 \\
\hline
\end{tabular}
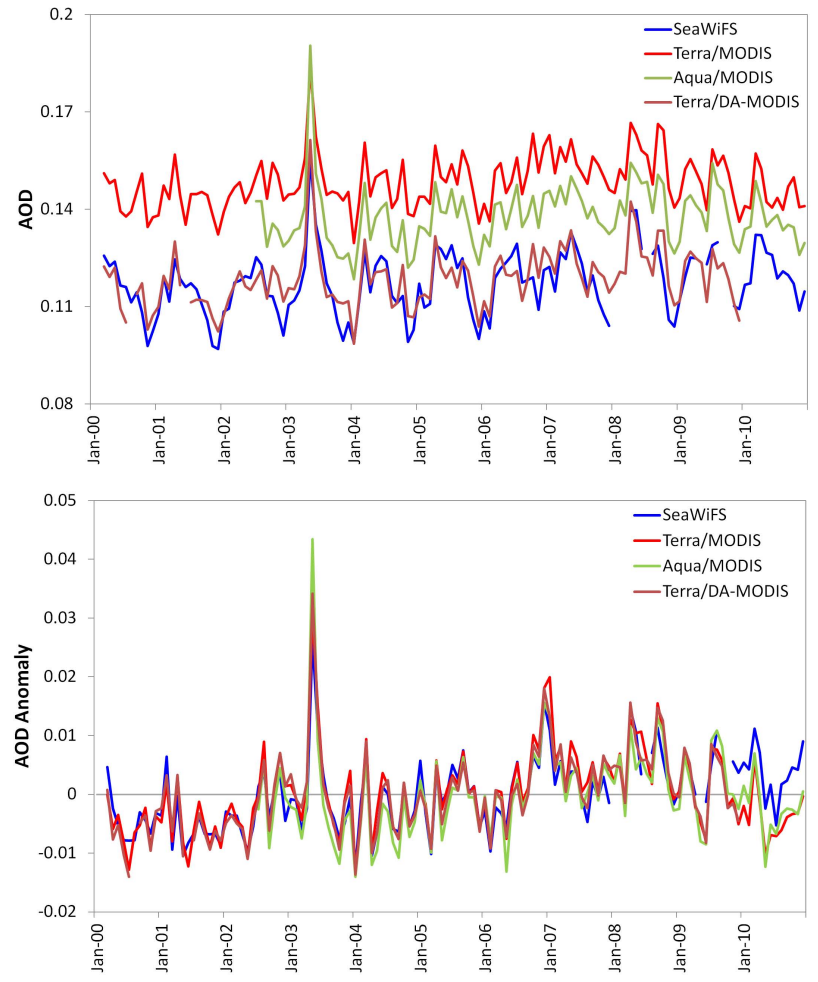

Fig. 7. Comparisons of the absolute AOD (top) and AOD anomaly (bottom) averaged over global ocean as a function of year between SeaWiFS and various MODIS products. The estimated linear trend is $0.00098 \mathrm{yr}^{-1}$ for SeaWiFS and $0.00061 \mathrm{yr}^{-1}$ for MODIS Terra. the Arabian Peninsula $\left(0.0092 \pm 0.0013 \mathrm{yr}^{-1}\right.$ with $\left|\omega / \sigma_{\omega}\right|$ of 7.18), while negligible trends of no statistical significance exist over most of the desert regions in China. In contrast, there is a negative tendency in the surrounding regions of the western part of North Africa as well as the Atlantic $\left(-0.0040 \pm 0.0014 \mathrm{yr}^{-1}\right.$ with $\left|\omega / \sigma_{\omega}\right|$ of 2.81$)$. This downward trend, which is most likely associated with the decreasing export of Saharan dust from North Africa into the Atlantic, is also reflected in the AERONET data at Capo Verde listed in Table 2 (which is significant at the $90 \%$ level, although not the $95 \%$ level). For fine mode anthropogenic aerosols, positive trends are observed in the fast developing countries over India $\left(0.0063 \pm 0.0020 \mathrm{yr}^{-1}\right.$ with $\left|\omega / \sigma_{\omega}\right|$ of 3.2) and southern China $\left(0.0049 \pm 0.0018 \mathrm{yr}^{-1}\right.$ with $\left|\omega / \sigma_{\omega}\right|$ of 2.69), most likely associated with an increase in urban/industrial pollution. Negative trends are also seen over eastern US $\left(-0.0028 \pm 0.0005 \mathrm{yr}^{-1}\right.$ with $\left|\omega / \sigma_{\omega}\right|$ of 4.73$)$ and Europe $\left(-0.0027 \pm 0.0007 \mathrm{yr}^{-1}\right.$ with $\left|\omega / \sigma_{\omega}\right|$ of 3.66$)$, which are consistent with the AERONET trends at GSFC and IFTLeipzig, respectively. The downward trends over Europe and the eastern US may partly be due to a decrease in pollution aerosols associated with emission control. For biomass burning regions, although there seems to be downward trend over the Central America, the estimated trends are not statistically significant for other areas such as South America, North America, Africa, and Southeast Asia. The comparisons of the magnitudes of global annual trends with these regional trends are summarized in Fig. 9.

It is also evident from the results shown in Table 2 that, except for Capo Verde and Venise, most of the island/coastal AERONET measurements exhibit either 


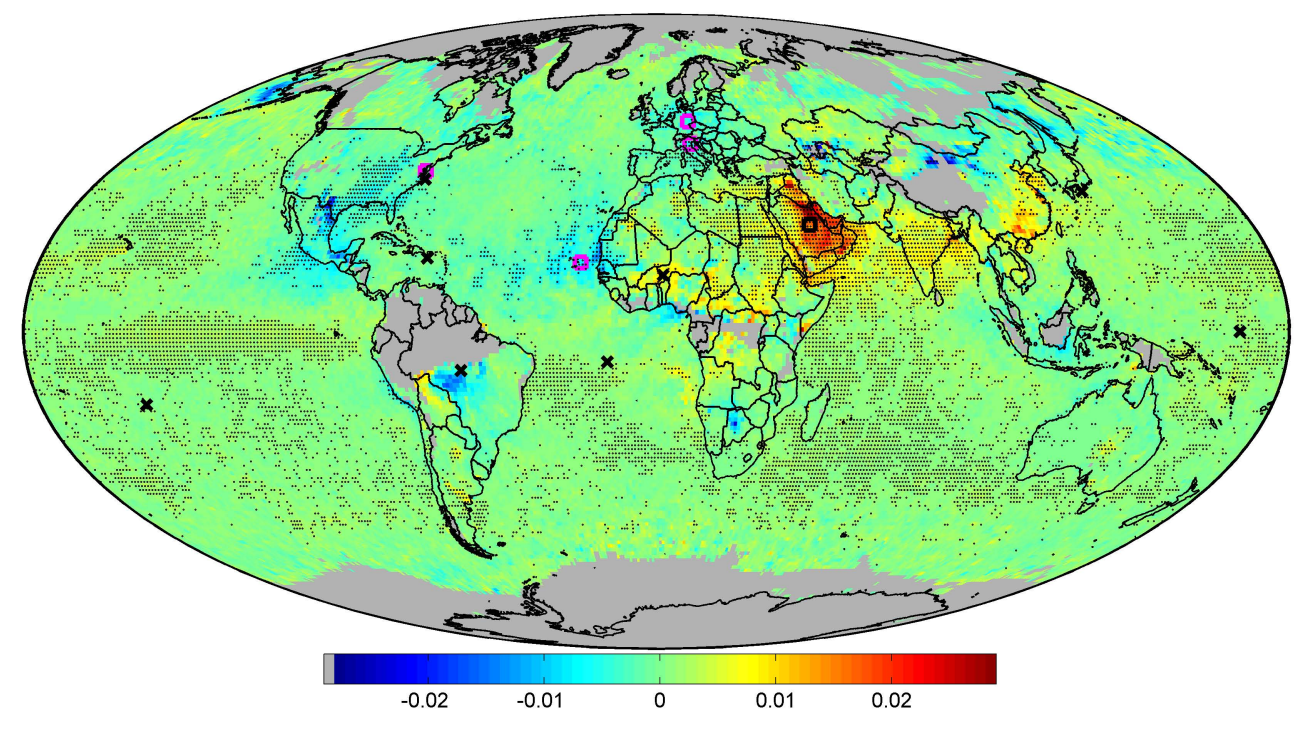

Fig. 8. Linear trend based upon deseasonalised monthly anomaly of AOD at $550 \mathrm{~nm}$ for the period 1998-2010. Units are AOD yr ${ }^{-1}$. Dots indicate significance at $95 \%$ confidence level. The black and pink boxes and symbol (x) represent the ground based AERONET locations with AOD tendency of positive, negative, and statistically insignificant values, respectively. Regions shaded in grey indicate no data or insufficient sample size for trend analysis.

positive or negligible trends over the tropical Pacific (Tahiti and Nauru), South Atlantic (Ascension Island), North Atlantic (COVE), Caribbean (La Parguera), and the northwest Pacific (Shirahama). The corresponding trends derived from the SeaWiFS record seem to be comparable to those from AERONET.

As stated in Sect. 2, the SeaWiFS equator crossing time had drifted from noon into a slightly later orbit after 2007. The changes in satellite overpass time could potentially lead to changes in the latitudinal range of sampling during daylight hours, or in cloud cover as part of the natural diurnal cycle as discussed above for the case of the AVHRR data. In order to examine if the drifted SeaWiFS orbit has significant impact on the sampling rate/coverage of the retrieved AOD throughout the $13 \mathrm{yr}$ of mission, we calculate the SeaWiFS AOD retrieval fraction (number of days with retrieved AOD relative to the total number of possible days) as function of time. Figure 10 (top panel) shows the global distribution of the $13 \mathrm{yr}$ averaged SeaWiFS AOD retrieval fraction (1997-2010). As expected, the regions with frequent cloudiness or snow/ice have poor retrieval rates such as those areas along storm tracks, ITCZ, and high latitude zones. The differences in SeaWiFS AOD retrieval fraction between early years (2000-2003) and later years (2007-2010) are also depicted in Fig. 10 (middle panel). The negative (positive) values are attributed to decreasing (increasing) sampling rate with time. It is clear that there are no systematic changes in the latitudinal range of AOD sampling in the later part of SeaWiFS mission as compared to the earlier period. However, there are some regionally dependent changes observed in AOD retrieval fractions, which are most likely due to changes in cloudiness during this time period. For comparison purpose, we also calculate the AOD retrieval fraction based upon the data from Terra/MODIS, which has maintained a stable equator crossing time around 10:30 a.m. during these overlapping years (i.e. 2000-2010). As shown in Fig. 10 (bottom panel), the patterns of cloudiness changes (the primary driver of retrieval availability) seen in the MODIS data during this period have many similarities with those in the SeaWiFS products and no significant bias was found between the two. It suggests that the later drift in SeaWiFS orbit does not result in substantial impact in sampling rate/coverage for trend calculations during its $13 \mathrm{yr}$ mission.

\subsection{Seasonal and regional trends}

Since, as shown in Fig. 1, there is strong seasonality in both the emission intensities of natural and anthropogenic aerosols over various source regions and their impact on large-scale aerosol distributions, trend analyses were performed separately for each season. Seasonal trends were calculated over each $1^{\circ} \times 1^{\circ}$ grid for the DJF, MAM, JJA and SON time spans and are presented in Fig. 11. The corresponding time series of seasonal mean AOD anomaly and their standard deviation over northern India $\left(20-30^{\circ} \mathrm{N}\right.$, $\left.75-85^{\circ} \mathrm{E}\right)$, eastern China $\left(30-40^{\circ} \mathrm{N}, 110-120^{\circ} \mathrm{E}\right)$, the Arabian Peninsula $\left(10-35^{\circ} \mathrm{N}, 35-60^{\circ} \mathrm{E}\right)$, Europe $\left(43-55^{\circ} \mathrm{N}, 0\right.$ $\left.30^{\circ} \mathrm{E}\right)$, and the eastern United States $\left(30-45^{\circ} \mathrm{N}, 70-90^{\circ} \mathrm{W}\right)$ are shown in Fig. 12. In order to have a reasonable temporal distribution in the analysis and maintain consistency with the estimation of annual trends, seasonal trends were computed based on the time series of individual months for a particular 


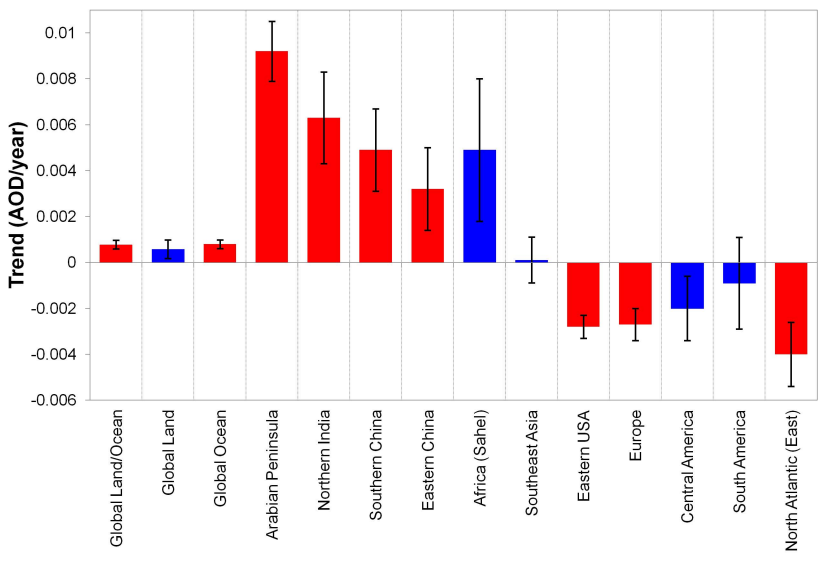

Fig. 9. Comparisons of global and regional annual trends based upon deseasonalised monthly anomaly of SeaWiFS AOD at $550 \mathrm{~nm}$ from January 1998 to December 2010. Units are AOD yr ${ }^{-1}$. Red bars represent regions with AOD trend statistically significant (exceeding $90 \%$ confidence), while blue bars indicate regions where statistically significant trend are not found (i.e. with $\left|\omega / \sigma_{\omega}\right|<1.65$ ). Error bars denote the uncertainty associated with the calculated trend.

season (stacked together), instead of calculating a seasonal mean trend. In other words, a slope coefficient was estimated from a time series consisting of MAM 1998, followed by MAM 1999 and so forth, thus from a total of 39 data points.

Unlike the annual time series, though, the seasonal time series contains successive gaps of 9 months; therefore the statistical significance of the seasonal trends were computed from the Student's t-test and not following the Weatherhead et al. (1998) method - which is more suitable for a time series without sequential breaks. The statistical significance of the seasonal trends was assessed using the Analysis Of Variance (ANOVA) procedure which involves testing the Fstatistic and associated p-value. The F-statistic is referred to as the ratio between mean-squared error of regression and mean-squared error of residuals, and is equal to the square of Student's t-statistic. The associated p-values (less than 0.05) are indicated as open symbols on global trend distribution maps for regions that are statistically significant at the $95 \%$ confidence level, and the null hypothesis (that the regression coefficients are not statistically different from zero) can be rejected.

Linear trends and their statistical significance at $95 \%$ confidence level are shown in Fig. 11 in the same fashion as in Fig. 8. The summary of the trend values and their associated uncertainties derived over selected sub-regions is also listed in Table 3 for each season. It is apparent that there are strong positive trends over both the Arabian Peninsula as well as the surrounding Arabian Sea, especially during spring and summer seasons $\left(0.0116 \pm 0.0015 \mathrm{yr}^{-1}\right.$ and $0.0140 \pm 0.0022 \mathrm{yr}^{-1}$, respectively). Strong upward trends are also found over the adjoining Persian Gulf. Thus, it

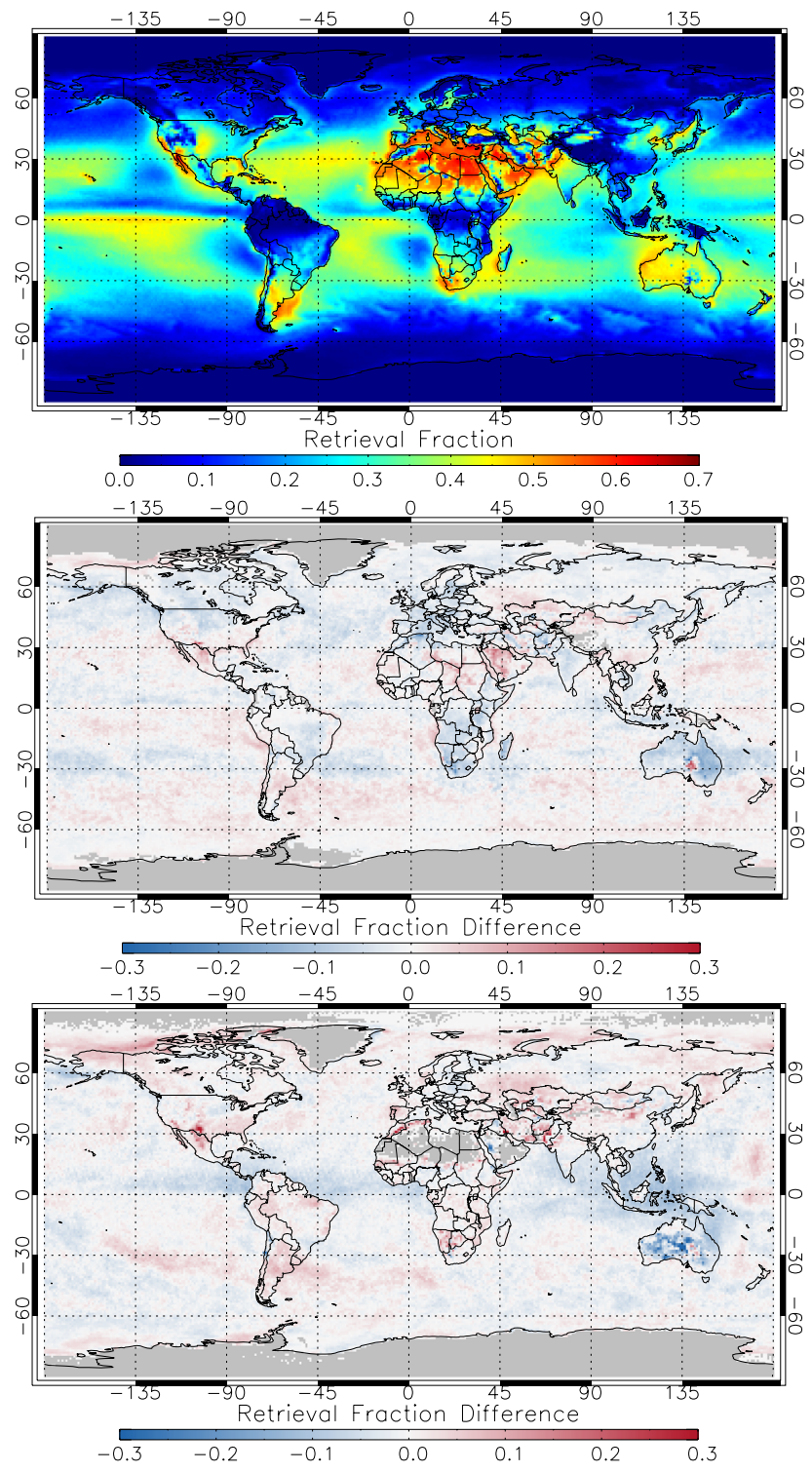

Fig. 10. (Top) $13 \mathrm{yr}$ averaged retrieval fraction of SeaWiFS AOD from 1997 to 2010 and (middle) the differences in SeaWiFS retrieval fraction between early years (2000-2003) and later years (2007-2010). For comparison, the differences in Terra/MODIS retrieval fraction between the same two periods are also shown (bottom).

is likely that the increasing aerosol load over the Arabian Peninsula, together with the increase over the northern Arabian Sea, has contributed to upward trends in AOD over surrounding oceanic regions largely associated with the springand summer-time dust outflow. We also found supporting evidence of a systematically increasing aerosol loading tendency from AERONET observations at Solar Village in Saudi Arabia, as well as a decreasing trend in Ångström exponent (440 nm-870 nm) for the period 1999-2010 (Fig. 13). Recently, Yoon et al. (2012) also reported an increasing 

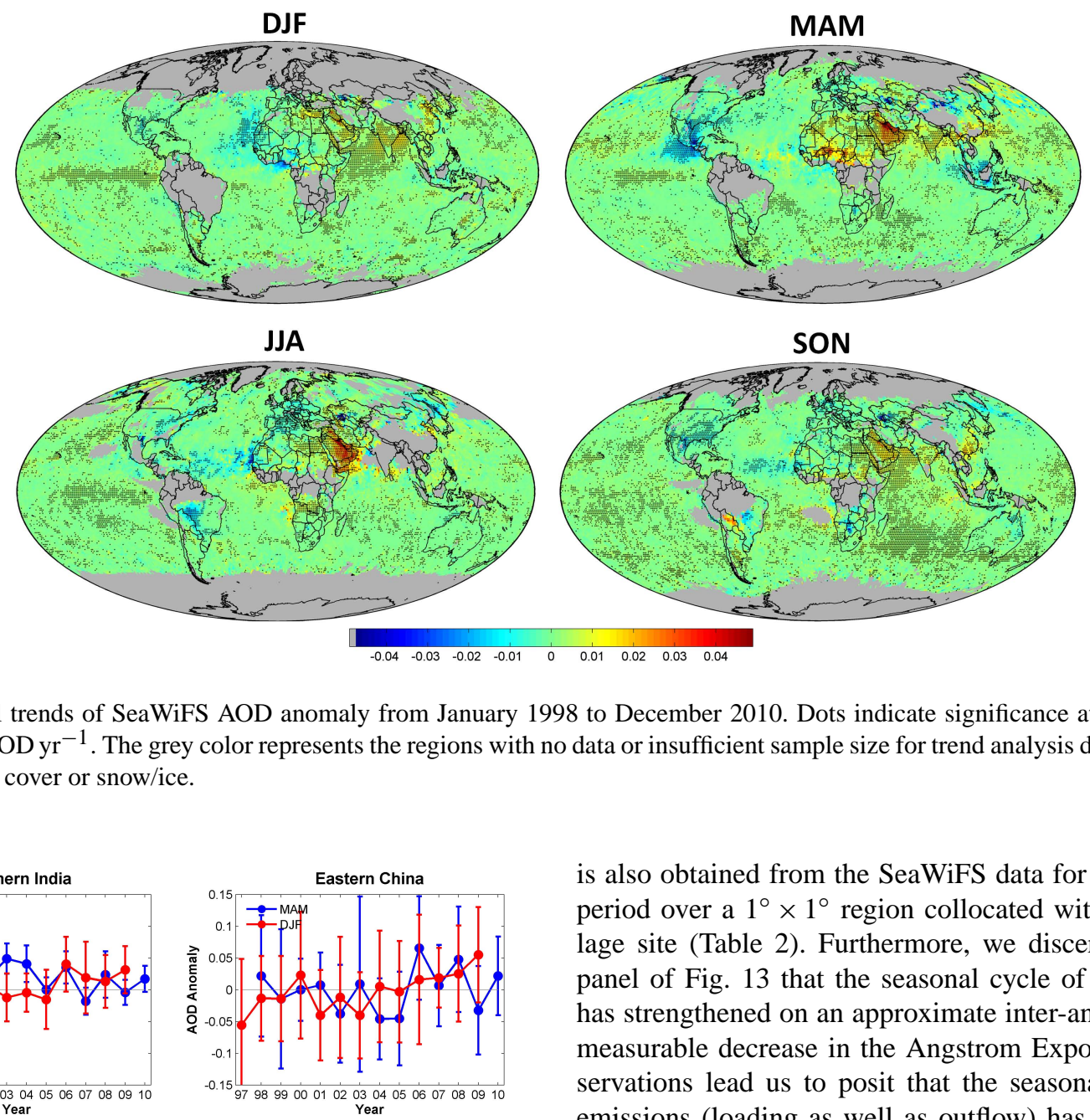

JJA

SON
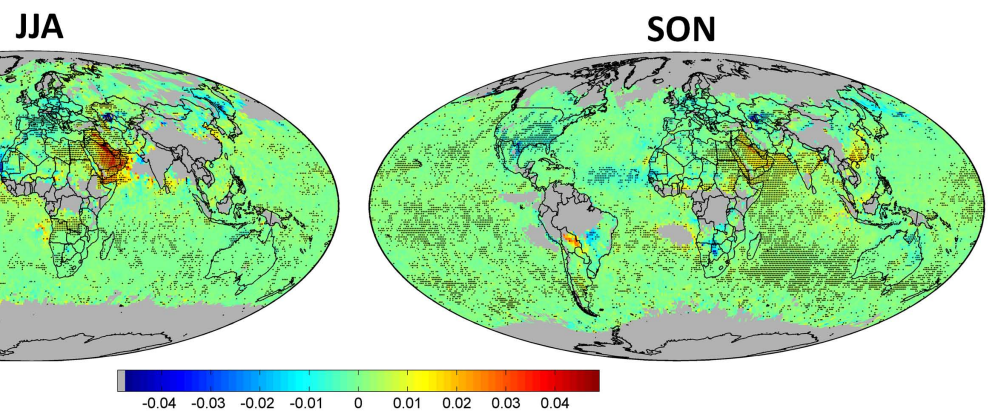

Fig. 11. Seasonal trends of SeaWiFS AOD anomaly from January 1998 to December 2010. Dots indicate significance at $95 \%$ confidence level. Units are AOD $\mathrm{yr}^{-1}$. The grey color represents the regions with no data or insufficient sample size for trend analysis due to the presence of frequent cloud cover or snow/ice.
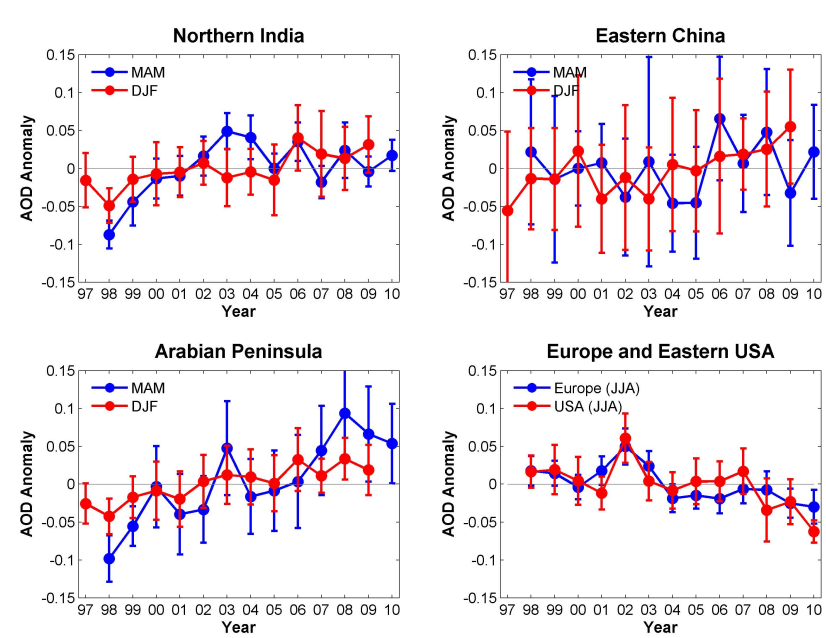

Fig. 12. SeaWiFS time series of seasonal averaged AOD anomaly over northern India $\left(20-30^{\circ} \mathrm{N}, 75-85^{\circ} \mathrm{E}\right)$, eastern China (30$\left.40^{\circ} \mathrm{N}, 110-120^{\circ} \mathrm{E}\right)$, Arabian Peninsula $\left(10-35^{\circ} \mathrm{N}, 35-60^{\circ} \mathrm{E}\right), \mathrm{Eu}-$ rope $\left(43-55^{\circ} \mathrm{N}, 0-30^{\circ} \mathrm{E}\right)$, and eastern United States $\left(30-45^{\circ} \mathrm{N}\right.$, $\left.70-90^{\circ} \mathrm{W}\right)$. The vertical bars denote the \pm 1 standard deviation of seasonal averaged AOD anomaly within the specified regions.

(decreasing) AOD (Ångström exponent) for the period 20012008, based on analysis of AERONET data from the Solar Village site. The upward trend in AOD from AERONET data is $0.018 \mathrm{yr}^{-1}$ and statistical significant at the $95 \%$ level for the 11-yr period shown in Fig. 13, while a positive trend (i.e. $0.0097 \mathrm{yr}^{-1}$ and statistical significant at the $95 \%$ level) is also obtained from the SeaWiFS data for the overlapping period over a $1^{\circ} \times 1^{\circ}$ region collocated with the Solar Village site (Table 2). Furthermore, we discern from the top panel of Fig. 13 that the seasonal cycle of aerosol loading has strengthened on an approximate inter-annual scale, with measurable decrease in the Angstrom Exponent. These observations lead us to posit that the seasonal cycle of dust emissions (loading as well as outflow) has strengthened in the past 11-13 yr spanning the AERONET and SeaWiFS data record over this region. The region-wide trend from the SeaWiFS AOD data record (January 1998 to December 2010) is estimated to be $0.0092 \mathrm{yr}^{-1}( \pm 0.0013)$ with $\left|\omega / \sigma_{\omega}\right|$ of 7.18 statistically significant at $95 \%$ level, when averaged over the Arabian Peninsula (Table 1). As clearly noted in the spatial trend distribution (Fig. 8), this large regional trend is an order of magnitude higher than the global mean trend (land and ocean) as well as the global mean trend only over land.

The global mean trend over land areas is weakly positive with large variability and is only representative for the relatively short time scale of the data record (a little over $13 \mathrm{yr}$ ) and therefore is deemed to be negligible or not scientifically significant. However, it is important to emphasize the large sustained upward trends observed over the Arabian Peninsula and the need to monitor future trends, and/or construct a longer-term aerosol record in retrospect to better quantify the changes in aerosol loading, causes and regional (and downwind) climate impacts.

In contrast to the strong upward trends over the Arabian Peninsula, there appears to be negative trends over the Saharan dust dominant regions in western African and 
Table 3. Seasonal trends derived based upon 13-yr SeaWiFS AOD products (January 1998-December 2010) for the same sub-regions as in Table 1 . The corresponding uncertainties are the $68 \%$ confidence limit. $* *$ indicates trends significant at $95 \%, *$ indicates trends significant at $90 \%$. Blank cells represent regions with insufficient sampling sizes for trend calculations within a given season.

\begin{tabular}{|c|c|c|c|c|}
\hline Season & DJF & MAM & JJA & SON \\
\hline \multicolumn{5}{|c|}{ Africa (Sahel) $10-15^{\circ} \mathrm{N}, 5^{\circ} \mathrm{W}-15^{\circ} \mathrm{E}$} \\
\hline Slope AOD/per year & -0.0037 & $0.0187 * *$ & 0.0043 & 0.0005 \\
\hline Uncertainty & 0.0048 & 0.0057 & 0.0034 & 0.0025 \\
\hline \multicolumn{5}{|c|}{ Arabian Peninsula $10-35^{\circ} \mathrm{N}, 35-60^{\circ} \mathrm{E}$} \\
\hline Slope AOD/per year & $0.0048 * *$ & $0.0116^{* *}$ & $0.0140 * *$ & $0.0065^{* *}$ \\
\hline Uncertainty & 0.0009 & 0.0015 & 0.0022 & 0.0010 \\
\hline \multicolumn{5}{|c|}{ Central America $5-20^{\circ} \mathrm{N}, 80-120^{\circ} \mathrm{W}$} \\
\hline Slope AOD/per year & 0.0002 & $-0.0084 * *$ & & 0.0006 \\
\hline Uncertainty & 0.0004 & 0.0030 & & 0.0004 \\
\hline \multicolumn{5}{|c|}{ Eastern China $35-40^{\circ} \mathrm{N}, 110-120^{\circ} \mathrm{E}$} \\
\hline Slope AOD/per year & $0.0078 * *$ & 0.0006 & & -0.0011 \\
\hline Uncertainty & 0.0023 & 0.0034 & & 0.0021 \\
\hline \multicolumn{5}{|c|}{ Southern China $20-30^{\circ} \mathrm{N}, 108-120^{\circ} \mathrm{E}$} \\
\hline Slope AOD/per year & $0.0047 * *$ & $0.0076^{* *}$ & & $0.0086^{* *}$ \\
\hline Uncertainty & 0.0020 & 0.0033 & & 0.0034 \\
\hline \multicolumn{5}{|c|}{ Europe $43-55^{\circ} \mathrm{N}, 0-30^{\circ} \mathrm{E}$} \\
\hline Slope AOD/per year & $-0.0020 * *$ & -0.0015 & $-0.0042^{* *}$ & $-0.0033^{* *}$ \\
\hline Uncertainty & 0.0009 & 0.0013 & 0.0011 & 0.0010 \\
\hline \multicolumn{5}{|c|}{ Northern India $20-30^{\circ} \mathrm{N}, 75-85^{\circ} \mathrm{E}$} \\
\hline Slope AOD/per year & $0.0053^{* *}$ & $0.0055^{* *}$ & & $0.0033^{*}$ \\
\hline Uncertainty & 0.0011 & 0.0020 & & 0.0017 \\
\hline \multicolumn{5}{|c|}{ Eastern USA $30-45^{\circ} \mathrm{N}, 70-90^{\circ} \mathrm{W}$} \\
\hline Slope AOD/per year & $-0.0009 * *$ & $-0.0029 * *$ & $-0.0047^{*}$ & $-0.0026^{* *}$ \\
\hline Uncertainty & 0.0004 & 0.0013 & 0.0016 & 0.0007 \\
\hline \multicolumn{5}{|c|}{ North Atlantic (east) $10-30^{\circ} \mathrm{N}, 18-30^{\circ} \mathrm{W}$} \\
\hline Slope AOD/per year & $-0.0068 * *$ & -0.0015 & $-0.0054^{*}$ & -0.0022 \\
\hline Uncertainty & 0.0026 & 0.0042 & 0.0029 & 0.0017 \\
\hline \multicolumn{5}{|c|}{ South America $10-20^{\circ} \mathrm{S}, 40-65^{\circ} \mathrm{W}$} \\
\hline Slope AOD/per year & & & $-0.0050 * *$ & \\
\hline Uncertainty & & & 0.0020 & \\
\hline \multicolumn{5}{|c|}{ Southeast Asia $15^{\circ} \mathrm{S}-10^{\circ} \mathrm{N}, 80-120^{\circ} \mathrm{E}$} \\
\hline Slope AOD/per year & 0.0004 & $-0.0027 * *$ & & 0.0024 \\
\hline Uncertainty & 0.0009 & 0.0009 & & 0.0017 \\
\hline
\end{tabular}

the North Atlantic, particularly during the winter season $\left(-0.0068 \pm 0.0026 \mathrm{yr}^{-1}\right)$. However, these patterns seem to coincide with the AOD-NAO correlation map depicted in Fig. 6. Therefore, the negative trend in the SeaWiFS AOD anomaly during the winter months is likely a reflection of the downward trend in the NAO strength from 1997 to 2010. Similarly, the locations of negative trends in the summer AOD anomaly over the Sahel and across the Atlantic also mimic the AOD-ENSO correlation shown in Fig. 5. Consequently, the large-scale meteorological processes, such as NAO and ENSO, largely regulate the export of the Saharan dust in the Atlantic. Overall, trends observed over the
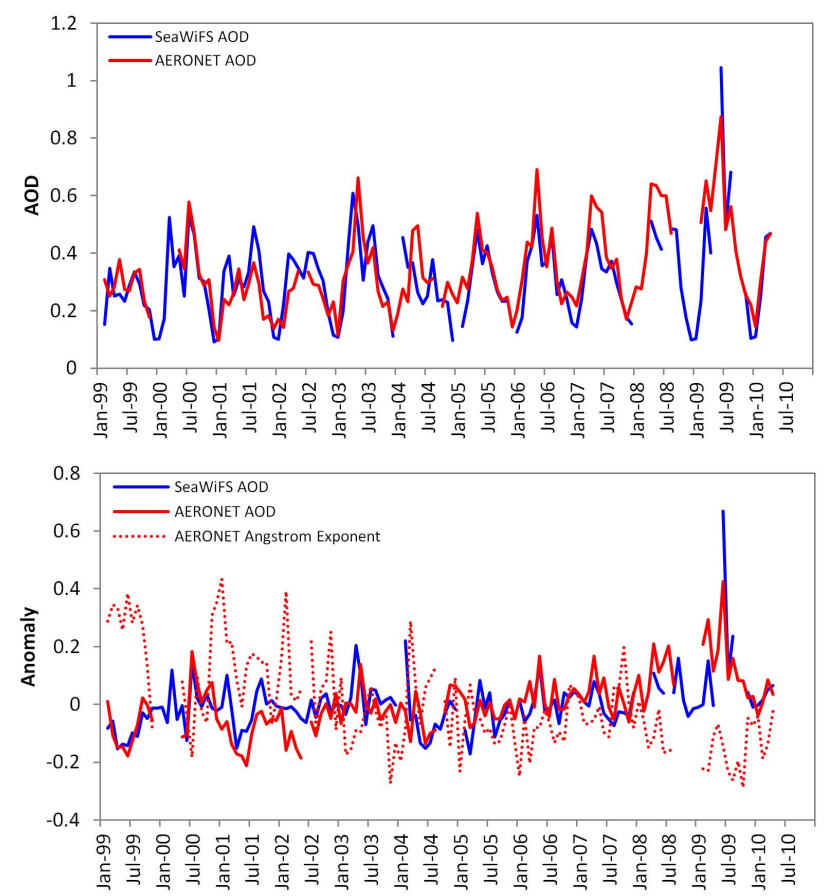

Fig. 13. Interannual variation of AOD (top panel) and AOD anomaly (bottom panel) from SeaWiFS and AERONET measurements co-located over the Solar Village site, for the period from February 1999 to April 2010. A systematic increasing aerosol loading signal is associated with the strengthening of the seasonal cycle, particularly during boreal spring and summer seasons, i.e. peak dust loading period. Interannual variations of Angstrom Exponent anomaly from AERONET data (bottom panel) also suggest a characteristic increase in coarse aerosol fraction.

North Africa exhibit relatively smaller trends with no statistical significance and weak seasonal dependency. However, there seems to be a significant positive trend over the Sahel region during springtime $\left(0.0187 \pm 0.0057 \mathrm{yr}^{-1}\right.$ with statistical significance at $95 \%$ ).

Over East Asia, aerosol loading appears to exhibit negligible trends of no statistical significance in eastern China $\left(0.0006 \pm 0.0034 \mathrm{yr}^{-1}\right)$ during the springtime active dust outbreak season; the corresponding AOD anomaly time series is depicted in Fig. 12 (top-right panel). The amount of mineral dust reaching this region decreases from 1998 to 2004-2005, but was quite high again in the later years (2006-2010). Overall, the insignificant trends for the dust-dominated season over eastern China are due to large interannual variability in the observed aerosol loading. In South Asia, the regions over northern India along the Indo-Gangetic plain are often influenced during the pre-monsoon season with heavy dust plumes transported from the Thar Desert in northwestern India (e.g. Gautam et al., 2011). Based upon Fig. 12 (top-left panel), these dust activities seem to increase significantly from 1998 and peak around 2003. However, since 2003 the dust intensity appears to have weakened during the 
boreal spring (MAM) compared to the prior period. A recent study based on satellite observations from MISR also alluded to this decrease in dust loading over northern India from 2000 onwards (Dey and Di Girolamo, 2011). However, since the SeaWiFS data record spans a longer time, our results indicate an overall slightly positive trend from 1998 to 2010 over northern India during this season $(0.0055 \pm 0.0020$ $\mathrm{yr}^{-1}$ with statistical significance at $95 \%$ ). For the rest of the world, there are no statistically-significant trends over arid and semi-arid regions, including over Australia and the southwest US.

For biomass burning regions such as Indonesia, South America, and in particular Central America, the aerosol trends are observed to be negative from 1998 to 2010. However, the year-to-year variabilities of smoke emission over these regions are most likely driven by the ENSO induced effects discussed in the previous section. Our calculations also show that there are no observed aerosol trends of statistical significance over Southeast Asia (i.e. Indo-China) as well as regions in North America, Europe, and Siberia where forest fires frequently occur.

Over regions where anthropogenic fine mode aerosols are prevalent, our study shows that there are downward trends of $-0.0047 \pm 0.0016 \mathrm{yr}^{-1}$ and $-0.0042 \pm 0.0011 \mathrm{yr}^{-1}$ in AOD over the eastern US and Europe, respectively, during the summer months (JJA) (i.e. the peak season of air pollution build-up in these regions). However, for the rapidly developing countries in Asia, the AOD tendencies are positive. In particular, during the heavy winter haze months (DJF), significant upward trends are observed in the regions of eastern and southern China $\left(0.0078 \pm 0.0023 \mathrm{yr}^{-1}\right.$ and $0.0047 \pm 0.0020 \mathrm{yr}^{-1}$, respectively), the East China Sea, and in northern and central India $\left(0.0053 \pm 0.0011 \mathrm{yr}^{-1}\right)$ and the surrounding oceanic regions, particularly over the Bay of Bengal. In contrast to the weak tendencies in the boreal spring/pre-monsoon months that are largely due to inter-annual variability of dust transport, the relatively stable conditions during dry winter/post-monsoon period favors accumulation of aerosols/pollutants. Hence, the upward trends are most likely due to increase in regional urban/industrial pollution. Yoon et al. (2011), using SeaWiFS data (with a different AOD retrieval algorithm) found positive trends in AOD during springtime and fall over the Pearl River delta in China; positive trends in this region are also seen in this study, although only statistically-significant on an annual, rather than seasonal scale due to frequent cloud cover. In terms of overall trends, it is interesting to note that both East and South Asia exhibit similar patterns during the high aerosol loading seasons, i.e. a systematic increasing trend during the winter haze period and a rather variable AOD distribution during the dust-dominant spring/pre-monsoon season (Fig. 12). A recent study also indicates upward trends in fine-mode anthropogenic aerosols over China and India using inventory emissions data for sulfate and carbonaceous aerosols (Lu et al., 2011).
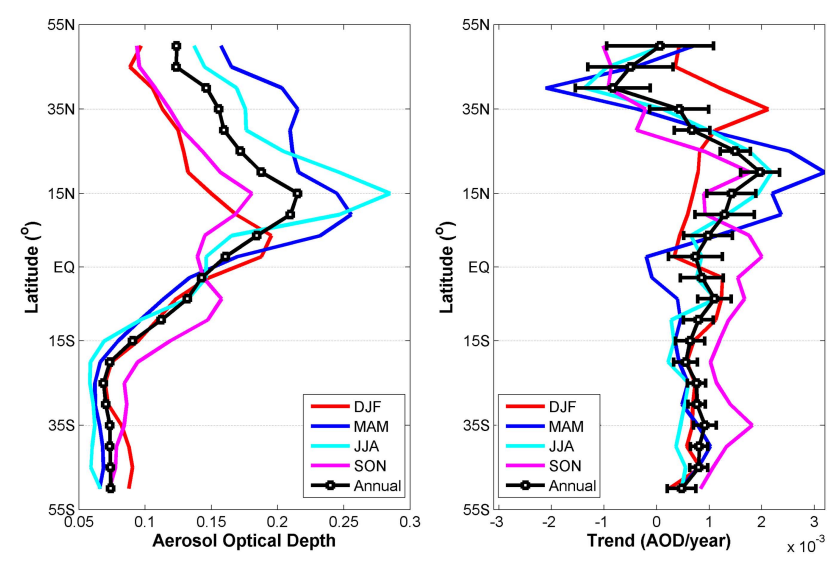

Fig. 14. The 13 yr SeaWiFS zonally averaged AOD values (left) and the corresponding trends per year (right) from $55^{\circ} \mathrm{S}$ to $55^{\circ} \mathrm{N}$ (land and ocean) for annual and four seasonal means denoted by different color lines. The horizontal bars on the right panel represent the uncertainties associated with the calculated annual trends for each latitude zone.

\subsection{Zonal average trend}

In order to help study the radiative effects of aerosols on Earth's climate, we also compute zonally averaged trends (averaged from $180^{\circ} \mathrm{W}$ to $180^{\circ} \mathrm{E}$ over both land and ocean) based upon this 13-yr SeaWiFS data record; these trends are displayed in Fig. 14 (right panel). Trends from zonal mean of AOD anomalies for both annual and seasonal averages are calculated and shown from $55^{\circ} \mathrm{S}$ to $55^{\circ} \mathrm{N}$ at $5^{\circ}$ intervals. The corresponding zonally-averaged absolute AOD values are also depicted in Fig. 14 (left panel) for comparison. As expected, the absolute AOD is much higher in the Northern Hemisphere compared to the Southern Hemisphere, which is mostly dominated by the oceans and is, in general, relatively pristine. Most of the tropospheric aerosol burden resides between the equator and $40^{\circ} \mathrm{N}$ for all four seasons, except for the springtime Asian dust outbreak which peaks at mid-latitudes in the Northern Hemisphere, and the biomass burning activities over South America, Africa, and Southeast Asia in the Southern Hemisphere during the boreal fall months (SON).

As shown in Fig. 14 (right panel), the corresponding overall annual trends are mostly positive over the latitude zone from equator to $30^{\circ} \mathrm{N}$, where most of the aerosol sources reside, although there are significant self-compensating positive and negative trends within this zone as depicted in Fig. 8. On a seasonal basis, the primary peak tendency in AOD occurs during the boreal winter months (DJF) around $25-40^{\circ} \mathrm{N}$ and is largely associated with changes over India and China as well as adjacent waters. However, the boreal springtime (MAM) zonal mean trends are slightly negative around $35-45^{\circ} \mathrm{N}$ due to weak decreases over the dust source regions in northwestern China, while remaining positive in 
the $10-30^{\circ} \mathrm{N}$ latitude zone as a result of larger increasing trends in the Arabian Peninsula dominating over the decreasing trend in Central America. The net positive trends over the tropics and subtropics in the Northern Hemisphere during boreal summer (JJA) are also a product of the strong increasing Arabian trends and the weaker decreasing trends in the Saharan dust dominant Atlantic Ocean. Compared to those in the Northern Hemisphere, the aerosol emissions in Southern Hemisphere, which are mostly related to biomass burning activities, peak in the SON months. Most of the aerosol tendency in this region is not statistically significant, especially near the smoke sources over land, due to large year-to-year fluctuation. However, a significant positive trend around $35^{\circ} \mathrm{S}$ is detected, which may be linked to the increasing amount of biomass burning smoke transported out of southern Australia and southeastern Africa. Overall, significant upward trends in annual mean AOD are found over the tropics and sub-tropics, which are largely amplified by the increasing dust emissions and outflow from the Arabian Peninsula during boreal spring and summer seasons.

\section{Conclusions}

Compared to other satellite sensors, SeaWiFS has unprecedentedly high accuracy and long-term stability (1-2\% and $0.3 \%$, respectively) in radiometric calibration as a result of rigorous lunar, solar and vicarious calibrations performed by the OBPG team. Therefore, the corresponding long-term drift in SeaWiFS AOD time series due to sensor calibration is negligible. However, as described in Sect. 1, several other factors in addition to calibration, such as retrieval algorithm deficiency or sampling bias due to orbital drift, could also contribute to the temporal variability of satellite retrieved AOD data records. In order to examine the effect of retrieval algorithm on trend analysis, we compare the SeaWiFS v003 AOD products against ground-based AERONET measurements acquired over the $13 \mathrm{yr}$ mission lifetime. The results indicate that there is no apparent year-to-year shift over either land or ocean between these two measurements. We also investigate the impact of potential sampling bias due to orbital drift by examining the temporal changes in latitudinal range and sampling rate of the SeaWiFS AOD retrievals. The differences in global distributions of SeaWiFS retrieval fractions are calculated between early years and later years and are found to be in general consistent with those for Terra/MODIS, which has maintained stable equator crossing time around 10:30 a.m. during the overlapping years. Therefore, this suggests that the SeaWiFS v003 data are suitable for estimating the interannual changes in AOD on both global and regional scales.

The resulting trend analyses based upon the SeaWiFS data from 1998 to 2010 show that the global annual trend of AOD during this period, although weakly positive (i.e. $0.00078 \pm 0.00019 \mathrm{yr}^{-1}$ ) and statistically significant at $95 \%$ level, is essentially negligible when compared to the magnitudes of contributions from other factors, including largescale meteorological events such as ENSO and NAO. Our estimated SeaWiFS trend over global ocean is comparable to and has the same sign as the trend derived from the MODIS sensors aboard Terra and Aqua. However, it is in opposite sign to AVHRR data during the overlapping years. On regional scales, the estimated trends in this study suggest that the AOD tendency could be significantly large. We note that there are decreasing trends over the eastern US and Europe, possibly due to a corresponding decrease in manmade air pollution levels. Yet, over rapidly developing countries such as China and India, significant increasing trends in $\mathrm{AOD}$ are seen in these source regions and their surrounding downwind oceans, particularly during the dry winter/postmonsoon months when the atmosphere is relatively stable, thus favoring accumulation of aerosols.

For the mineral dust-dominated parts of the world, strong positive trends are detected over the Arabian Peninsula and the adjacent waters. In contrast, a negative tendency is observed in the emission and export of Saharan dust over the western North Africa and the North Atlantic. Overall, based on $13 \mathrm{yr}$ of data, a relatively contrasting pattern in trends appears to have emerged in the tropics/subtropics largely modulated by dust emissions and transport processes encompassing the Saharan arid lands and the Arabian Peninsula and their downwind oceanic regions, with downward and upward tendencies, respectively.

In order to reduce the uncertainty in estimating climate forcing caused by tropospheric aerosols, it is important to produce the best quality climatology of aerosol properties with sufficient data length by merging aerosol information obtained from the multiple satellite sensors that are currently available. SeaWiFS data extend from 1997 to 2010, which has many overlapping years with MODIS, MISR, AVHRR, and TOMS, and thus provides a good benchmark to characterize instrument drifts due to calibration for other satellite measurements. However, $13 \mathrm{yr}$ of satellite measurements is barely enough to establish long-term trends of aerosols, particularly in those regions where the ENSO or other largescale climatic factors could play a large role in modulating aerosol variability. Therefore, it is imperative to continue the high quality-EOS aerosol data records from SeaWiFS and MODIS with Visible and Infrared Imager Radiometer Suite (VIIRS) measurements onboard the currently operational Suomi NPP satellite, and to be flown on future JPSS satellites, to achieve the statistically adequate length of data records necessary for climate studies.

Acknowledgements. This work was supported by the NASA MEaSUREs program, managed by Martha Maiden. The authors gratefully acknowledge the efforts made by the SeaWiFS Ocean Biology Processing Group for producing the SeaWiFS level 1 data, the SeaDAS software, and NCEP meteorological fields for SeaWiFS retrievals. We would also like to express our gratitude to 
several AERONET PIs in establishing and maintaining the longterm stations used in this investigation. We thank Jianglong Zhang for providing DA-MODIS product and his helpful guidance on improving the robustness of the statistical methodology. Appreciations also extend to Jingfeng Huang for useful discussions related to Saharan dust activity and ENSO. Elizabeth Weatherhead is thanked for a very useful discussion concerning trend detection, significance, and autocorrelation. We are also grateful for the three anonymous reviewers for useful comments that helped improve an earlier version of the manuscript.

Edited by: E. Highwood

\section{References}

Chen, Y., Randerson, J. T., Morton, D. C., DeFries, R. S., Collatz, G. J., Kasibhatla, P. S., Giglio, L., Jin, Y., and Marlier, M. E.: Forecasting fire season severity in South America using sea surface temperature anomalies, Science, 334, 787-791, 2011.

Chiapello, I., Moulin, C., and Prospero, J. M.: Understanding the long-term variability of African dust transport across the Atlantic as recorded in both Barbados surface concentrations and large-scale Total Ozone Mapping Spectrometer (TOMS) optical thickness, J. Geophys. Res., 110, D18S10, doi:10.1029/2004JD005132, 2005.

de Meij, A., Pozzer, A., and Leilieveld, J.: Trend analysis in aerosol optical depths and pollutant emission estimates between 2000 and 2009, Atmos. Environ., 51, 75-86, doi:10.1016/j.atmosenv.2012.01.059, 2012.

Devasthale, A., Karlsson, K.-G., Quaas, J., and Grassl, H.: Correcting orbital drift signal in the time series of AVHRR derived convective cloud fraction using rotated empirical orthogonal function, Atmos. Meas. Tech., 5, 267-273, doi:10.5194/amt-5-2672012, 2012.

Dey, S. and Di Girolamo, L.: A decade of change in aerosol properties over the Indian subcontinent, Geophys. Res. Lett., 38, L14811, doi:10.1029/2011GL048153, 2011.

Eplee Jr., R. E., Meister, G., Patt, F. S., Franz, B. A., and McClain, C. R.: Uncertainty assessment of the SeaWiFS on-orbit calibration, Proc. SPIE, 8153, 815310, 2011.

Ginoux, P., Prospero, J., Torres, O., and Chin, M.: Long-term simulation of global dust distribution with the GOCART model: Correlation with North Atlantic Oscillation, Environ. Modell. Software, 19, 113-128, 2004.

Gautam, R., Hsu, N. C., Tsay, S. C., Lau, K. M., Holben, B., Bell, S., Smirnov, A., Li, C., Hansell, R., Ji, Q., Payra, S., Aryal, D., Kayastha, R., and Kim, K. M.: Accumulation of aerosols over the Indo-Gangetic plains and southern slopes of the Himalayas: distribution, properties and radiative effects during the 2009 pre-monsoon season, Atmos. Chem. Phys., 11, 1284112863, doi:10.5194/acp-11-12841-2011, 2011.

Gordon, H. R.: Atmospheric correction of ocean color imagery in the Earth Observing System era, J. Geophys. Res., 102, 1708117106, 1997.

Holben, B. N., Eck, T. F., Slutsker, I., Tanre, D., Buis, J. P., Setzer, A., Vermote, E., Reagan, J. A., Kaufman, Y., Nakajima, T., Lavenu, F., Jankowiak, I., and Smirnov, A.: AERONET - A federated instrument network and data archive for aerosol characterization, Remote Sens. Environ., 66, 1-16, 1998.
Hsu, N. C., Tsay, S.-C., King, M. D., and Herman, J. R.: Aerosol properties over bright-reflecting source regions, IEEE T. Geosci. Remote Sens., 42, 557-569, 2004.

Hsu, N. C., Tsay, S.-C., King, M. D., and Herman, J. R.: Deep Blue retrievals of Asian aerosol properties during ACE-Asia, IEEE T. Geosci. Remote Sens., 44, 3180-3195, 2006.

Hurrell, J. W.: Decadal trend in the North Atlantic Oscillation: regional temperatures and precipitations, Science, 269, 676-679, 1995.

Intergovernmental Panel on Climate Change (IPCC): The scientific basis, Cambridge University Press, Cambridge, UK and New York, NY, USA, 996 pp., 2007.

Levy, R. C., Remer, L. A., Kleidman, R. G., Mattoo, S., Ichoku, C., Kahn, R., and Eck, T. F.: Global evaluation of the Collection 5 MODIS dark-target aerosol products over land, Atmos. Chem. Phys., 10, 10399-10420, doi:10.5194/acp-10-10399-2010, 2010.

Li, Z., Zhao, X., Kahn, R., Mishchenko, M., Remer, L., Lee, K.-H., Wang, M., Laszlo, I., Nakajima, T., and Maring, H.: Uncertainties in satellite remote sensing of aerosols and impact on monitoring its long-term trend: a review and perspective, Ann. Geophys., 27, 2755-2770, doi:10.5194/angeo-27-2755-2009, 2009.

Lu, Z., Zhang, Q., and Streets, D. G.: Sulfur dioxide and primary carbonaceous aerosol emissions in China and India, 1996-2010, Atmos. Chem. Phys., 11, 9839-9864, doi:10.5194/acp-11-98392011, 2011.

McClain, C. R., Cleave, M. L., Feldman, G. C., Gregg, W. W., Hooker, S. B., and Kuring, N.: Science quality SeaWiFS data for global biospheric research, Sea Technol., 39, 10-16, 1998.

Mishchenko, M. I., Geogdzhayev, I. V., Rossow, W. B., Cairns, B., Carlson, B. E., Lacis, A. A., Liu, L., and Travis, L. D.: Long-term satellite record reveals likely recent aerosol trend, Science, 315, 1543, doi:10.1126/science.1136709, 2007.

Prospero, J. M. and Lamb, P. J.: African droughts and dust transport to the Caribbean: Climate change implications, Science, 302, 1024-1027, 2003.

Ramanathan, V., Crutzen, P. J., Kiehl, J. T., and Rosenfeld, D.: Aerosols, climate and the hydrological cycle, Science, 294, 2119-2124, 2001.

Rosenfeld, D., Lohmann, U., Raga, G. B., O’Dowd, C. D., Kulmala, M., Fuzzi, S., Reissell, A., and Andreae, M. O.: Flood or drought: How do aerosols affect precipitation?, Science, 321, 1309-1313, doi:10.1126/science.1160606, 2008.

Sayer, A. M., Hsu, N. C., Bettenhausen, C., Ahmad, Z., Holben, B. N., Smirnov, A., Thomas, G. E., and Zhang, J.: SeaWiFS Ocean Aerosol Retrieval (SOAR): algorithm, validation, and comparison with other datasets, J. Geophs. Res, 117, D03206, doi:10.1029/2011JD016599, 2012a.

Sayer, A. M., Hsu, N. C., Bettenhausen, C., Jeong, M.-J., Holben, B. N., and Zhang, J.: Global and regional evaluation of overland spectral aerosol optical depth retrievals from SeaWiFS, Atmos. Meas. Tech., 5, 1761-1778, doi:10.5194/amt-5-1761-2012, 2012b.

Sen, P. K.: Estimates of the regression coefficient based on Kendall's tau, J. Amer. Stat. Assoc., 63, 1379-1389, 1968.

Shi, Y., Zhang, J., Reid, J. S., Holben, B., Hyer, E. J., and Curtis, C.: An analysis of the collection 5 MODIS over-ocean aerosol optical depth product for its implication in aerosol assimilation, Atmos. Chem. Phys., 11, 557-565, doi:10.5194/acp-11-557-2011, 2011. 
Smirnov, A., Holben, B. N., Eck, T. F., Dubovik, O., and Slutsker, I.: Cloud-Screening and Quality Control Algorithms for the AERONET Database, Remote Sens. Environ., 73, 337-349, doi:10.1016/S0034-4257(00)00109-7, 2000.

Smirnov, A., Holben, B. N., Eck, T. F., Slutsker, I., Chatenet, B., and Pinker, R. T.: Diurnal variability of aerosol optical depth observed at AERONET (Aerosol Robotic Network) sites, Geophys. Res. Lett., 29, 2115, doi:10.1029/2002GL016305, 2002.

Theil, H.: A rank-invariant method of linear and polynomial regression analysis. I, II, III, Nederl. Akad. Wetensch., Proc. 53, 386392, 521-525, 1397-1412, 1950.

Thomas, G. E., Poulsen, C. A., Siddans, R., Sayer, A. M., Carboni, E., Marsh, S. H., Dean, S. M., Grainger, R. G., and Lawrence, B. N.: Validation of the GRAPE single view aerosol retrieval for ATSR-2 and insights into the long term global AOD trend over the ocean, Atmos. Chem. Phys., 10, 4849-4866, doi:10.5194/acp-10-4849-2010, 2010.

Weatherhead, E. C., Reinsel, G. C., Tiao, G. C., Meng, X.-L., Choi, D., Cheang, W.-K., Keller, T., DeLuisi, J., Wuebbles, D. J., Kerr, J. B., Miller, A. J., Oltmans, S. J., and Frederick, J. E.: Factors affecting the detection of trends: Statistical considerations and applications to environmental data, J. Geophys. Res., 103, 1714917161, doi:10.1029/98JD00995, 1998.

Wolter, K. and Timlin, M. S.: Monitoring ENSO in COADS with a seasonally adjusted principal component index. Proc. of the 17th Climate Diagnostics Workshop, Norman, OK, NOAA/NMC/CAC, NSSL, Oklahoma Clim. Survey, CIMMS and the School of Meteor., Univ. of Oklahoma, 52-57, 1993.
Wolter, K. and Timlin, M. S.: Measuring the strength of ENSO events - how does 1997/98 rank?, Weather, 53, 315-324, 1998.

Yoon, J., von Hoyningen-Huene, W., Vountas, M., and Burrows, J. P.: Analysis of linear long-term trend of aerosol optical thickness derived from SeaWiFS using BAER over Europe and South China, Atmos. Chem. Phys., 11, 12149-12167, doi:10.5194/acp11-12149-2011, 2011.

Yoon, J., von Hoyningen-Huene, W., Kokhanovsky, A. A., Vountas, M., and Burrows, J. P.: Trend analysis of aerosol optical thickness and Ångström exponent derived from the global AERONET spectral observations, Atmos. Meas. Tech., 5, 12711299, doi:10.5194/amt-5-1271-2012, 2012.

Zhang, J. and Reid, J. S.: MODIS aerosol product analysis for data assimilation: Assessment of over-ocean level 2 aerosol optical thickness retrievals, J. Geophys. Res., 111, D22207, doi:10.1029/2005JD006898, 2006.

Zhang, J. and Reid, J. S.: A decadal regional and global trend analysis of the aerosol optical depth using a data-assimilation grade over-water MODIS and Level 2 MISR aerosol products, Atmos. Chem. Phys., 10, 10949-10963, doi:10.5194/acp-1010949-2010, 2010.

Zhao, T. X.-P., Laszlo, I., Guo, W., Heidinger, A., Cao, C., Jelenak, A., Tarpley, D., and Sullivan, J.: Study of long-term trend in aerosol optical thickness observed from operational AVHRR satellite instrument, J. Geophys. Res., 113, D07201, doi:10.1029/2007JD009061, 2008. 